\title{
Articles
}

\section{Multicomponent Synthesis of N-Heterocyclic Carbene Complexes}

\author{
Robin S. Bon, ${ }^{\dagger}$ Frans J. J. de Kanter, ${ }^{\dagger}$ Martin Lutz, ${ }^{\ddagger}$ Anthony L. Spek, ${ }^{\ddagger}$ Mareike C. Jahnke, ${ }^{\S}$ \\ F. Ekkehardt Hahn, ${ }^{\S}$ Marinus B. Groen,${ }^{\dagger}$ and Romano V. A. Orru* ${ }^{* \dagger}$ \\ Department of Organic and Inorganic Chemistry, Faculty of Science, Vrije Universiteit Amsterdam, \\ De Boelelaan 1083, 1081 HV Amsterdam, The Netherlands
}

Received February 23, 2007

\begin{abstract}
$\mathrm{N}$-Heterocyclic carbenes (NHCs) are valuable ligands in transition metal catalysis, due to their unique electronic properties. However, only a few routes toward unsymmetrically substituted, saturated NHCs are known. We have successfully applied the multicomponent synthesis of $2 \mathrm{H}$-2-imidazolines for the preparation of a range of diversely substituted imidazolidin-2-ylidene complexes under mild conditions. In the desired NHC precursors the substituents at N-1, N-3, C-4, and C-5 were varied easily and independently by choosing the appropriate amine, aldehyde, isocyanide, or halide as starting material. Subsequent formation of the imidazolium salts followed by deprotonation with $\mathrm{KO}^{t} \mathrm{Bu}$ and direct complexation of the in situ-generated NHCs at room temperature affords $\mathrm{Rh}-$ and $\mathrm{Ir}-\mathrm{NHC}$ complexes. Properties of the resulting complexes were studied with ${ }^{13} \mathrm{C}$ NMR spectroscopy and X-ray crystallography.
\end{abstract}

\section{Introduction}

$\mathrm{N}-$ Heterocyclic carbenes (NHCs) attract considerable attention as valuable ligands in coordination chemistry and homogeneous catalysis. ${ }^{1}$ This can be attributed to some rather unique properties of NHC ligands, such as their stronger $\sigma$-donor ability compared to, for example, tertiary phosphine ligands. Further, their strong nucleophilic character and weak $\pi$ back-donating ability make NHC ligands comparable to $\mathrm{P}$ - or $\mathrm{N}$-donating ligands rather than to classical Fischer- or Schrock-type carbenes. ${ }^{2}$ Important advantages of NHC metal complexes are their low sensitivity to air (oxidation), heat, and moisture compared to the corresponding phosphine complexes. ${ }^{3}$ As a result, NHC ligands serve as good alternatives to electron-rich phosphine ligands, which makes them increasingly popular in transition metal (TM) catalysis. ${ }^{1}$ In addition to beneficial electronic properties robust synthetic procedures give access to NHCs bearing additional

\footnotetext{
* Corresponding author. E-mail: orru@few.vu.nl.

Vrije Universiteit Amsterdam. Fax: (+31) 20-598-7488. E-mail: orru@few.vu.nl.

$\doteqdot$ Bijvoet Center for Biomolecular Research, Crystal and Structural Chemistry, Utrecht University, Padualaan 8, 3584 CH Utrecht, The Netherlands.

§ Institut für Anorganische und Analytische Chemie, Westfälische Wilhelms-Universität Münster, Corrensstr. 36, D-48149 Münster, Germany.

(1) For reviews see: (a) Bourissou, D.; Guerret, O.; Gabbai, F. P.; Bertrand, G. Chem. Rev. 2000, 100, 39-92. (b) Herrmann, W. A. Angew. Chem., Int. Ed. 2002, 41, 1290-1309. (c) Herrmann, W. A.; Weskamp, T.; Böhm, V. P. W. Adv. Organomet. Chem. 2001, 48, 1-69. (d) Hillier, A. C.; Grasa, G. A.; Viciu, M. S.; Lee, H. M.; Yang, C.; Nolan, S. J. Organomet. Chem. 2002, 653, 69-82. (e) Bedford, R. B.; Cazin, C. S. J.; Holder, D. Coord. Chem. Rev. 2004, 248, 2283-2321. (f) Trnka, T. M.; Grubbs, R. H. Acc. Chem. Res. 2001, 34, 18-29. (g) Peris, E.; Crabtree, R. H. Coord. Chem. Rev. 2004, 248, 2239-2246. (h) Crabtree, R. H. J. Organomet. Chem. 2005, 690, 5451-5457. (i) Hahn, F. E. Angew. Chem., Int. Ed. 2006, 45, 1348-1352.

(2) Lee, M. T.; Hu, C. H. Organometallics 2004, 23, 976-983.

(3) Herrmann, W. A.; Roesky, P. W.; Elison, M.; Artus, G. R.; Öfele, K. Organometallics 1995, 14, 1085-1086.
}

functional groups, leading to easily recoverable catalysts, ${ }^{4}$ water- ${ }^{5}$ or methanol ${ }^{6}$-soluble catalysts, and catalysts containing "flexible steric bulk"7 as well as chiral ligands ${ }^{8 a}$ and bidentate and pincer ligands, ${ }^{1 \mathrm{f}, 9}$ although it should be noted that the potential of monodentate NHC complexes for asymmetric catalysis is believed to be only modest. ${ }^{8 b-8 d}$
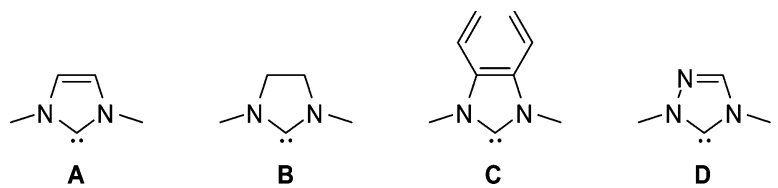

Figure 1. Commonly used N-heterocyclic carbenes.

NHCs derived from three-, four-, six-, and seven-membered

(4) Süssner, M.; Plenio, H. Angew. Chem., Int. Ed. 2005, 44, 68856888 .

(5) Hong, S. H.; Grubbs, R. H. J. Am. Chem. Soc. 2006, 128, 35083509.

(6) Hahn, F. E.; Paas, M.; Fröhlich, R. J. Organomet. Chem. 2005, 690, $5816-5821$

(7) (a) Altenhoff, G.; Goddard, R.; Lehmann, C. W.; Glorius, F. Angew. Chem., Int. Ed. 2003, 42, 3690-3693. (b) Lavallo, V.; Canac, Y.; Präsang, C.; Donnadieu, B.; Bertrand, G. Angew. Chem., Int. Ed. 2005, 44, 57055709.

(8) (a) Seiders, T. J.; Ward, D. W.; Grubbs, R. H. Org. Lett. 2001, 3, 3225-3228. (b) Rivas, F. M.; Riaz, U.; Giessert, A.; Smulik, J. A.; Diver, S. T. Org. Lett. 2001, 3, 2673-2676. (c) Baskakov, D.; Herrmann, W. A.; Herdtweck, E.; Hoffmann, S. D. Organometallics 2007, 26, 626-632.

(9) (a) For a recent review on bidentate carbenes see: Cabeza, J. A.; da Silva, I.; del Rio, I.; Sanchez-Vega, M. G. Dalton Trans. 2006, 39663971. For other examples, see also: (b) Hahn, F. E.; Jahnke, M. C.; GomesBenitez, V.; Morales-Morales, D.; Pape, T. Organometallics 2005, 24, 6458-6463. (c) Hahn, F. E.; Jahnke, M. C.; Pape, T. Organometallics 2006, 25, 5927-5936. (d) Slootweg, J. C.; Chen, P. Organometallics 2006, 25, $5863-5869$ 
Scheme 1. Syntheses of Imidazolinium Salts

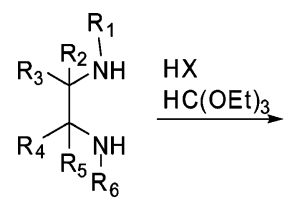

1

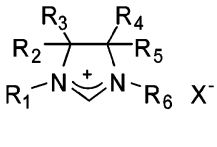

2

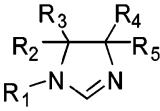

3

heterocycles have been reported. ${ }^{10-13}$ However, the most frequently used NHC ligands are the five-membered imidazolin2-ylidenes A, imidazolidin-2-ylidenes B, benzimidazolin-2ylidenes C, and triazolin-2-ylidenes D (Figure 1). A straightforward procedure to synthesize the "saturated" carbenes $\mathbf{B}$ is by deprotonation of the corresponding imidazolinium salts $\mathbf{B H}^{+} \mathbf{X}^{-}$with bases such as $\mathrm{NaH}, \mathrm{KH}, \mathrm{LDA}, \mathrm{KHMDS}$, or $\mathrm{KO}^{t_{-}}$ $\mathrm{Bu}$. The imidazolinium salts $\mathbf{B H}^{+} \mathbf{X}^{-}$can be obtained by condensation of 1,2-diamines with triethyl orthoformate. A quick way to generate symmetrically substituted 1,2-diamines is via reduction of 1,2-diimines or via amination of 1,2-dibromides. ${ }^{14}$ Variation of the C-4 and C-5 side groups of carbenes of type $\mathbf{B}$ can in principle be achieved by using available 1,2-diamines $\mathbf{1}$ or by alkylation of imidazolines $\mathbf{3}$ containing various $\mathrm{R}^{1}-\mathrm{R}^{5}$ groups (Scheme 1). However, methods for the synthesis of NHCs containing distinct side groups in the carbon backbone $\left(\mathrm{R}^{2}-\mathrm{R}^{5}\right)$ are limited. In fact, the only general procedure involves a one-pot synthesis of imidazolidin-2-thiones followed by reduction of its thiourea moiety, ${ }^{15}$ although the harsh reaction conditions are only compatible with nonfunctionalized alkyl substituents.

Recently, we reported a versatile multicomponent synthesis of $2 \mathrm{H}$-2-imidazolines $7 .{ }^{16}$ The mild reaction conditions render this multicomponent reaction (MCR) compatible with a broad spectrum of aliphatic, aromatic, heteroaromatic, and olefinic substituents and even with more delicate functional groups such as amines, alcohols, esters, and primary chlorides. Because the substituents on C-4 and C-5 of the resulting $2 \mathrm{H}$-2-imidazolines can be varied independently, we envisioned this MCR as a valuable tool for the synthesis of unprecedented types of NHCtransition metal complexes. In this contribution, we report a

(10) (a) Schumann, H.; Glanz, M.; Girgsdies, F.; Hahn, F. E.; Tamm, M.; Grzegorzewski, A. Angew. Chem., Int. Ed. 1997, 36, 2232-2234. (b) Lavallo, V.; Canac, Y.; Donnadieu, B.; Schoeller, W. W.; Bertrand, G. Science 2006, 312, 722-724. (c) Lavallo, V.; Ishida, Y.; Donnadieu, B.; Bertrand, G. Angew. Chem., Int. Ed. 2006, 45, 6652-6655.

(11) (a) Despagnet-Ayoub, E.; Grubbs, R. H. J. Am. Chem. Soc. 2004 126, 10198-10199. (b) Despagnet-Ayoub, E.; Grubbs, R. H. Organometallics 2005, 24, 338-340. (c) Ishida, Y.; Donnadieu, B.; Bertrand, G. Proc. Natl. Acad. Sci. 2006, 103, 13585-13588.

(12) (a) Alder, R. W.; Blake, M. E.; Bortolotti, C.; Butts, C. P.; Linehan, E.; Oliva, J. M.; Orpen, A. G.; Quayle, M. J. Chem. Commuun. 1999, 241242. (b) Guillen, F.; Winn, C. L.; Alexakis, A. Tetrahedron: Asymmetry 2001, 12, 2083-2086. (c) Bazinet, P.; Yap, G. P. A.; Richeson, D. S. J. Am. Chem. Soc. 2003, 125, 13314-13315.

(13) (a) Scarborough, C. C.; Grady, M. J. W.; Guzei, I. A.; Gandhi, B. A.; Bunel, E. E.; Stahl, S. S. Angew. Chem., Int. Ed. 2005, 44, 52695272. (b) Scarborough, C. C.; Popp, B. V.; Guzei, I. A.; Stahl, S. S. J. Organomet. Chem. 2005, 690, 6143-6155.

(14) (a) Arduengo, A. J., III; Krafczyk, R.; Schmutzler, R.; Craig, H. A.; Goerlich, J. R.; Marshall, W. J.; Unverzagt, M. Tetrahedron 1999, 55, 14523-14534. (b) Delaude, L.; Szypa, M.; Demonceau, A.; Noels, A. F. Adv. Synth. Catal. 2002, 344, 749-756.

(15) (a) Hahn, F. E.; Paas, M.; Le Van, D.; Lügger, T. Angew. Chem., Int. Ed. 2003, 42, 5243-5246. (b) Hahn, F. E.; Paas, M.; Fröhlich, R. Chem.-Eur. J. 2005, 11, 5080-5085. (c) Hahn, F. E.; Le Van, D.; Paas, M.; Fröhlich, R. Dalton Trans. 2006, 860-864.

(16) (a) Bon, R. S.; Hong, C.; Bouma, M. J.; Schmitz, R. F.; de Kanter, F. J. J.; Lutz, M.; Spek, A. L.; Orru, R. V. A. Org. Lett. 2003, 5, 37593762. (b) Bon, R. S.; van Vliet, B.; Sprenkels, N. E.; Schmitz, R. F.; de Kanter, F. J. J.; Stevens, C. V.; Swart, M.; Bickelhaupt, F. M.; Groen, M. B.; Orru, R. V. A. J. Org. Chem. 2005, 70, 3542-3553.

Scheme 2. Multicomponent Approach toward NHC Complexes

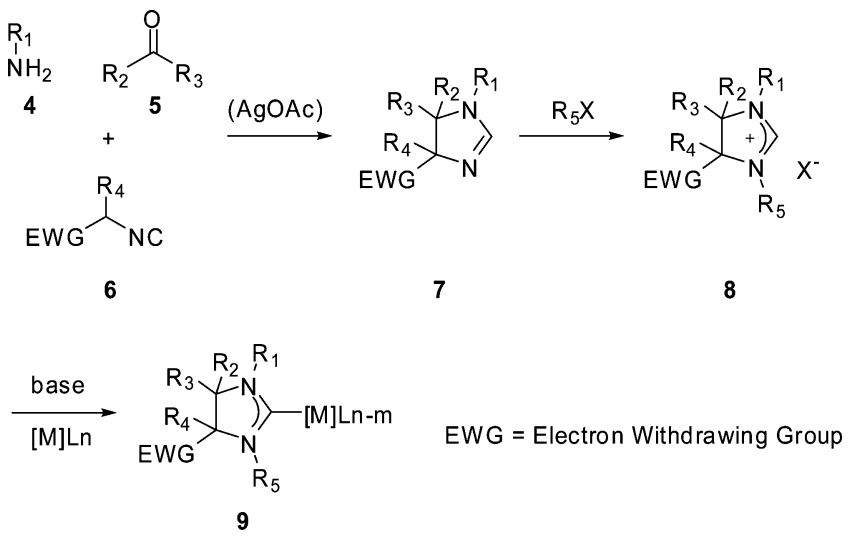

Chart 1. Building Blocks for NHC Precursors

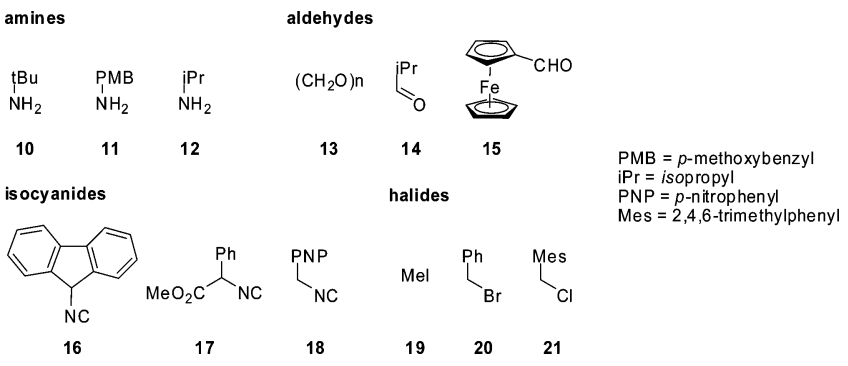

very short and flexible synthetic protocol for the synthesis of a structurally diverse set of $\mathrm{Rh}-$ and $\mathrm{Ir}-\mathrm{NHC}$ metal complexes of type 9 (Scheme 2). All substituents $\mathrm{R}^{1}-\mathrm{R}^{5}$ at N-1, N-3, C-4, and $\mathrm{C}-5$ in 9 were varied easily and independently by choosing an appropriate amine, aldehyde, isocyanide, or halide as starting materials.

\section{Results and Discussion}

For the synthesis of a diverse set of NHC precursors $\mathbf{8}$, three amines, three aldehydes, three isocyanides, and three halides were chosen (Chart 1). Thus, after the synthesis of 2-imidazolines 22, 25, 27, 29, and 31, which proceeds smoothly via our three-component approach, alkylation gives the corresponding imidazolinium halides 23, 24, 26, 28, 30, and 32 in high yields (Table 1; entries 1-6). Although conversions are generally quantitative, small amounts of the product are sometimes lost during washing of the salts with ether or pentane. Quarternization with 19 or 20 can be performed in $\mathrm{CH}_{2} \mathrm{Cl}_{2}$, but for the less reactive chloride $\mathbf{2 1}$, more polar solvents such as DMF are preferred (entry 2).

Imidazolinium salts $\mathbf{2 3}$ and $\mathbf{2 4}$ seemed useful to investigate since it is known that free NHCs are stabilized toward dimerization by one or two bulky N-substituents. Application of ferrocene carboxaldehyde $\mathbf{1 5}$ as the aldehyde component in our MCR gives easy access to 4-ferrocenyl-substituted 2-imidazoline 27, and subsequent alkylation with MeI affords the corresponding imidazolinium salt $\mathbf{2 8}$ (entry 4) as an interesting NHC precursor. Such NHC ligands with ferrocenyl substituents in the carbon backbone are not yet studied, although NHCs and NHC complexes containing (remote) ferrocenyl substituents at 
Table 1. Synthesis of Imidazol(in)ium Salts

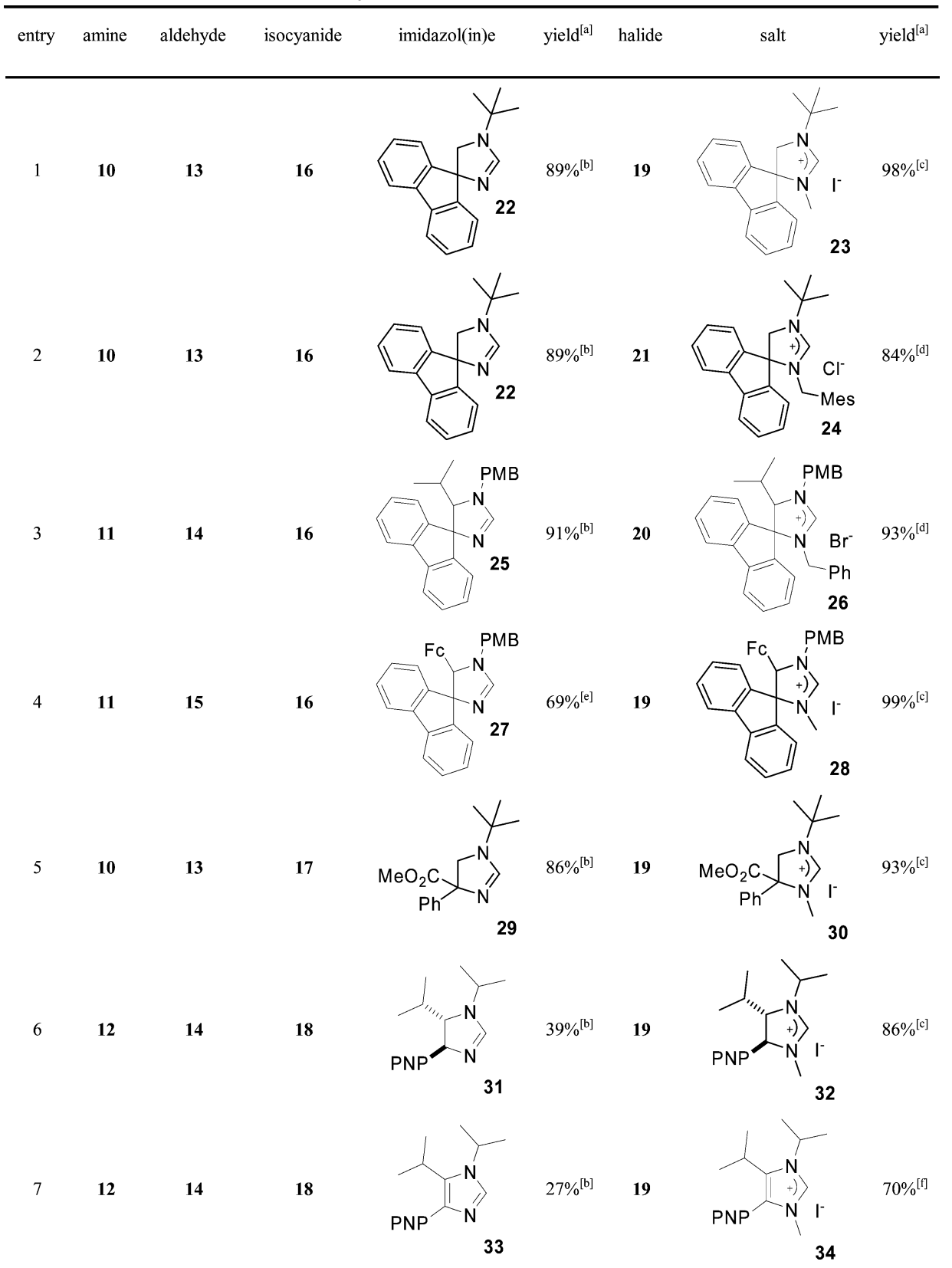

${ }^{a}$ Isolated yields are reported. ${ }^{b}$ Conditions: $\mathrm{Na}_{2} \mathrm{SO}_{4}, \mathrm{CH}_{2} \mathrm{Cl}_{2}$, rt, $18 \mathrm{~h}$, see also ref $16 .{ }^{c}$ Conditions: $\mathrm{R}-\mathrm{X}, \mathrm{CH}_{2} \mathrm{Cl}_{2}$, $\mathrm{rt}, 18 \mathrm{~h}$. ${ }^{d}$ Conditions: $\mathrm{R}-\mathrm{X}, \mathrm{DMF}, \mathrm{rt}$, 18 h. ${ }^{e}$ Conditions: $\mathrm{MeOH}, \mathrm{rt}, 18 \mathrm{~h}$. ${ }^{f}$ Conditions: 8 equiv of $\mathrm{MeI}, \mathrm{CH}_{2} \mathrm{Cl}_{2}, 100{ }^{\circ} \mathrm{C}$ (microwave), 20 min. Mes = 2,4,6-trimethylphenyl; PMB $=p$-methoxybenzyl; $\mathrm{Fc}=$ ferrocenyl; PNP $=p$-nitrophenyl.

the nitrogens have been reported. ${ }^{17}$ Recently, even the generation of a metallocene-fused imidazol-2-ylidene and its mercury complex was reported. ${ }^{18}$ An elegant application of NHCs with redox-active ferrocenyl groups in an easily recyclable olefin metathesis catalyst has been described by Plenio. ${ }^{6}$ In addition, also the imidazole $\mathbf{3 3}^{16}$ was used as NHC precursor in order to compare unsymmetrically substituted imidazolidin-2-ylidenes

(17) (a) Bildstein, B.; Malaun, M.; Kopacka, H.; Ongania, K.-H.; Wurst, K. J. Organomet. Chem. 1998, 552, 45-61. (b) Bildstein, B.; Malaun, M.; Hopacka, H.; Wurst, K.; Mitterböck, M.; Ongania, K.-H.; Opromolla, G.; Zanello, P. Organometallics 1999, 18, 4325-4336. (c) Bolm, C.; Kesselgruber, M.; Raabe, G. Organometallics 2002, 21, 707-710. (d) Seo, H.; Park, H.; Kim, B. Y.; Lee, J. H.; Son, S. U.; Chung, Y. K. Organometallics 2003, 22, 618-620.

(18) (a) Arduengo, A. J., III; Tapu, D.; Marshall, W. J. Angew. Chem., Int. Ed. 2005, 44, 7240-7244. (b) Arduengo, A. J., III; Tapu, D.; Marshall, W. J. J. Am. Chem. Soc. 2005, 127, 16400-16401. with their unsaturated analogues. Methylation of imidazole 33 was successful using microwave heating and an excess of MeI and gave the corresponding salt $\mathbf{3 4}$ in good yield (entry 7). The imidazol(in)ium salts were all isolated as stable but somewhat hygroscopic solids.

Deprotonation of $\mathbf{2 3}$ with $\mathrm{NaH}$ followed by refluxing with $[\mathrm{Rh}(\operatorname{cod}) \mathrm{Cl}]_{2}$ in $\mathrm{THF}$ provided the stable, crystalline $\mathrm{NHC}$ complex 35 in 52\% yield (Table 2, entry 1). Replacement of the chloride on rhodium by the iodide that was present in $\mathbf{2 3}$ was confirmed by mass spectroscopy and X-ray crystallography (Figure 2). To ensure complete substitution of chloride by iodide, excess KI was added to the reaction mixture. Although deprotonation of imidazolinium salts is usually faster with $\mathrm{KO}^{t}$ $\mathrm{Bu}$ than with $\mathrm{NaH}$, tert-butanol reacts with the resulting carbenes to form their corresponding alcohol adducts, which can be liberated again at elevated temperatures. Instead, a one-pot 


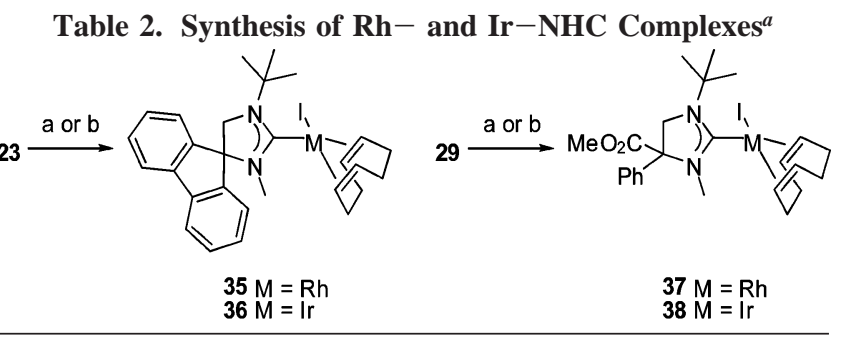

\begin{tabular}{ccccc}
\hline entry & compound & method & yield & ratio $^{b}$ \\
\hline 1 & $\mathbf{3 5}$ & $\mathrm{a}$ & $52 \%$ & \\
2 & $\mathbf{3 5}$ & $\mathrm{b}$ & $82 \%$ & \\
3 & $\mathbf{3 6}$ & $\mathrm{a}$ & $55 \%$ & \\
4 & $\mathbf{3 6}$ & $\mathrm{b}$ & $63 \%$ & \\
5 & $\mathbf{3 7}$ & $\mathrm{a}$ & $51 \%$ & $89: 11$ \\
6 & $\mathbf{3 7}$ & $\mathrm{b}$ & $63 \%$ & $78: 22$ \\
7 & $\mathbf{3 8}$ & $\mathrm{a}$ & $51 \%$ & $52: 48$ \\
8 & $\mathbf{3 8}$ & $\mathrm{b}$ & $49 \%{ }^{c}$ & $57: 43$
\end{tabular}

${ }^{a}$ Reagents and conditions: (a) (1) NaH, THF, rt, 18 h; (2) $[\mathrm{Rh}(\operatorname{cod}) \mathrm{Cl}]_{2}$, $\mathrm{KI}$ (xs), reflux, $20 \mathrm{~h}$; (b) $\mathrm{KO}^{t} \mathrm{Bu},[\mathrm{Rh}(\operatorname{cod}) \mathrm{Cl}]_{2}, \mathrm{KI}, \mathrm{rt}, 18 \mathrm{~h}$. ${ }^{b}$ Isolated yields and ratios are reported. Ratios refer to relative amounts of rotamers. ${ }^{c}$ This yield could be improved by performing the reaction in refluxing THF: $57 \%$ (67:33).

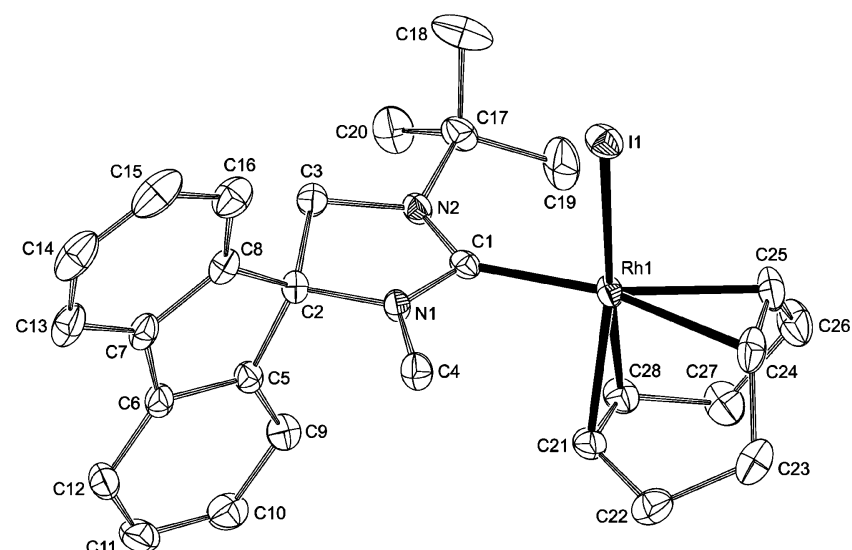

Figure 2. Displacement ellipsoid plot of $\mathbf{3 5}$ drawn at the $50 \%$ probability level. Hydrogen atoms are omitted for clarity. Selected bond lengths $[\AA]$, angles [deg], and torsion angles [deg]: I1-Rh1 2.70624(17), Rh1-C1 2.0197(14), N1-C1 1.3481(18), N2-C1 1.3576(19); I1-Rh1-C1 86.10(4), Rh1-C1-N1 120.53(10), $\mathrm{Rh} 1-\mathrm{C} 1-\mathrm{N} 2$ 131.58(10), N1-C1-N2 107.88(12); I1-Rh1-C1$\mathrm{N} 1-85.36(11)$.

reaction between $23, \mathrm{KO}^{t} \mathrm{Bu}, \mathrm{KI}$, and $[\mathrm{Rh}(\operatorname{cod}) \mathrm{Cl}]_{2}$ at room temperature results in deprotonation of $\mathbf{2 3}$ followed by trapping of the in situ-generated NHC, giving rhodium complex 35 in $82 \%$ yield (entry 2 ). Apparently, halogen exchange already takes place at room temperature.

Both the two-step and the one-step method were used for the synthesis of several rhodium and iridium complexes. The NHC complexes 35-38 were isolated as stable, crystalline solids. In general, the one-step deprotonation and complexation (method b) gives higher yields (entries 1-6). The yield of IrNHC complex 38 could be enhanced by performing the reaction in refluxing THF (entry 8). Also at iridium, halogen exchange already takes place at room temperature.

The NMR spectra of $\mathbf{3 7}$ and $\mathbf{3 8}$ show double sets of signals, which are caused by the formation of rotamers. Rotation of the carbene ligand around the TM-NHC axis is hindered for steric reasons. High-temperature NMR experiments have shown that this rotation does not occur once the complex has formed. In the case of iridium complex $\mathbf{3 8}$, the rotational isomers could be

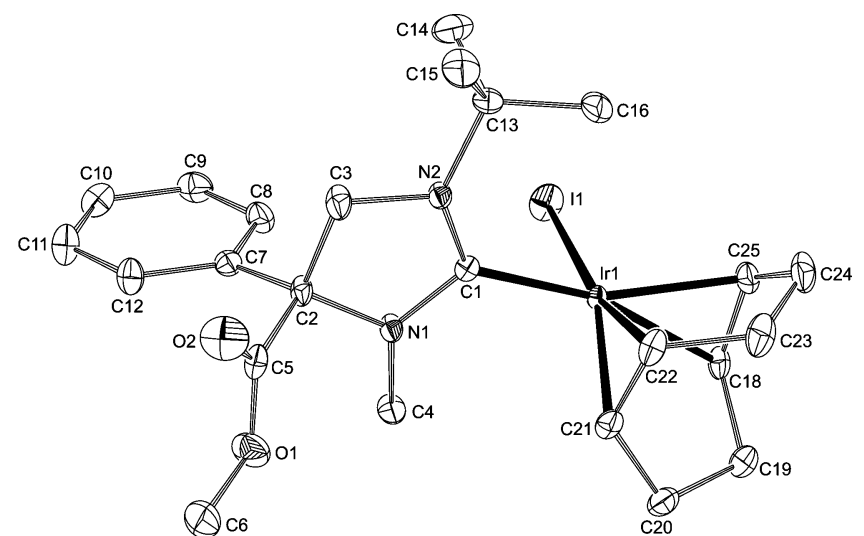

Figure 3. Displacement ellipsoid plot of 38a, the major, least polar isomer of $\mathbf{3 8}$, drawn at the $50 \%$ probability level. Hydrogen atoms are omitted for clarity. Selected bond lengths $[\AA]$, angles [deg], and torsion angles [deg]: Ir1-I1 2.67288(19), Ir1-C1 2.023(2), N1-C1 1.354(3), N2-C1 1.343(3); I1-Ir1-C1 90.11(6), Ir1C1-N1 121.82(15), Ir1-C1-N2 129.67(16), N1-C1-N2 108.48(19); I1-Ir1-C1-N1 89.20(17).

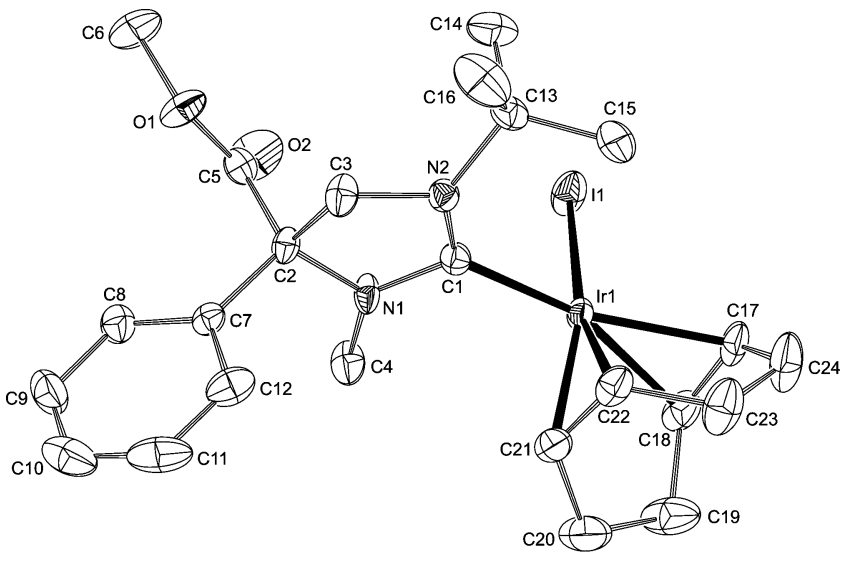

Figure 4. Displacement ellipsoid plot of $\mathbf{3 8 b}$, the minor, most polar isomer of 38, drawn at the $50 \%$ probability level. Hydrogen atoms are omitted for clarity. Selected bond lengths $[\AA]$, angles [deg], and torsion angles [deg]: Ir1-I1 2.6716(2), Ir1-C1 2.030(3), N1C1 1.344(3), N2-C1 1.351(3); I1-Ir1-C1 92.09(7), Ir1-C1-N1 121.34(18), Ir1-C1-N2 129.94(19), N1-C1-N2 108.2(2); I1$\mathrm{Ir} 1-\mathrm{C} 1-\mathrm{N} 186.9(2)$.

separated using flash column chromatography. ${ }^{20}$ Ultimate proof for the existence of the two rotational isomers was provided by $\mathrm{X}$-ray crystal structure analysis of the two products. In the major, least polar fraction of $\mathbf{3 8}$, the carboxylic ester and the iodide are on opposite sides of the NHC plane (Figure 3), while in the minor, most polar fraction, they are on the same side (Figure 4).

Several methods exist to circumvent halogen exchange during the formation of TM-NHC complexes. For example, an azolium salt containing a noncoordinating anion can be used as precursor. ${ }^{21}$ Imidazolinium hexafluorophosphate $\mathbf{3 9}$ can be obtained in nearly quantitative yield from reaction of imidazolinium iodide 30 with $\mathrm{AgPF}_{6}$ (Scheme 3). This reaction is driven by the precipitation of AgI from the DCM solution. Deprotonation of $\mathbf{3 9}$ and in situ complexation of the resulting carbene

(19) Small differences in ratios depicted in Table 2 may be attributed to small losses during chromatographic purification.

(20) Heating a solution of a single rotamer of $\mathbf{3 8}$ in toluene- $d_{8}$ at $150{ }^{\circ} \mathrm{C}$ (microwave) for $30 \mathrm{~min}$ does not provide a mixture of rotamers. At $200{ }^{\circ} \mathrm{C}$, the product decomposes completely.

(21) Baker, M. V.; Brayshaw, S. K.; Skelton, B. W.; White, A. H. Inorg. Chim. Acta 2004, 357, 2841-2849. 
Scheme 3. Multicomponent Approach toward NHC Complexes
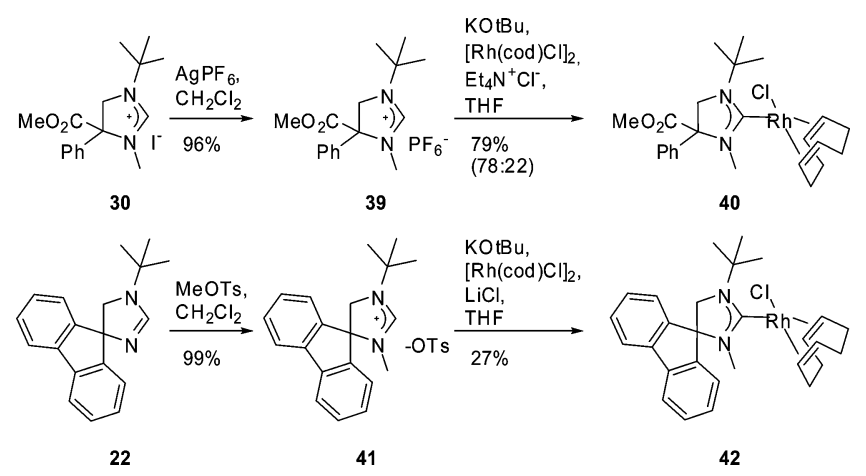

gave chloro complex $\mathbf{4 0}$ in high yield as a mixture of rotamers. When the same reaction sequence was applied to imidazolinium iodide 23, an inseparable mixture of chloro complex $\mathbf{4 2}$ and bis(carbene) complex $\mathrm{Rh}(\mathrm{cod})(\mathrm{NHC})_{2} \cdot \mathrm{PF}_{6}$ was isolated. Consequently, complex $\mathbf{4 2}$ was synthesized from imidazolinium tosylate 41, which was obtained in quantitative yield by alkylation of imidazoline $\mathbf{2 2}$ with methyl tosylate. In this case, the contaminating bis(carbene) complex, as its tosylate salt, can be easily removed by washing with water.

Rhodium (and iridium)-NHC complexes are being increasingly applied as catalysts for, among others, (asymmetric) hydrosilylations ${ }^{22}$ and cycloaddition reactions. ${ }^{23}$ Furthermore, an established method for determining the ligand properties of NHCs involves studying $\mathrm{Rh}-\mathrm{NHC}$ complexes. ${ }^{24}$ In order to compare our NHCs, we decided to synthesize a broader range of unsymmetrically substituted NHC complexes of rhodium (Table 3). Our one-step deprotonation/complexation procedure proved compatible with all imidazol(in)ium salts from Table 1 and provided complexes $\mathbf{4 3 - 4 7}$ in reasonable to high yields. Again, chiral NHCs gave rise to mixtures of rotamers (entries 2-4). The major isomers of $\mathbf{4 4}$ and $\mathbf{4 6}$ could be obtained as pure compounds easily by slow crystallization. Complexes $\mathbf{4 4}$, 46, and 47 were studied using X-ray crystal structure analysis.

Interestingly, crystals of the major isomer of complex 44 undergo a solid-solid phase transition upon cooling. The hightemperature phase $44-\mathrm{I}$ crystallizes in the centrosymmetric space group $P 2{ }_{1} / n$ with one independent molecule in the asymmetric unit (Figure 5). Close to the isopropyl group there is a small void. The low-temperature phase 44-II crystallizes in the noncentrosymmetric space group $P 2_{1}$, which is a subgroup of $P 2_{1} / n$ (Figure 6). In the $P 2_{1}$ phase there are two independent molecules in the asymmetric unit, which differ mainly in the conformation of the isopropyl group. Additionally, due to the phase transition, there are significant changes of intermolecular distances, which make the packing motif of 44-II incompatible with $P 2_{1} / n$. Over a wide temperature range $(110-250 \mathrm{~K})$ both phases are present. The different molecular structures show only

(22) (a) Chianese, A. R.; Crabtree, R. H. Organometallics 2005, 24, 4432-4436. (b) Viviano, M.; Mas-Marzá, E.; Sanaú, M.; Peris, E. Organometallics 2006, 25, 3063-3069. (c) Herrmann, W. A.; Baskakov, D.; Herdtweck, E.; Hoffmann, S. D.; Bunlaksananusorn, T.; Rampf, F.; Rodefeld, L.; Organometallics 2006, 25, 2449-2456.

(23) (a) Evans, P. A.; Baum, E. W.; Fazal, A. N.; Pink, M. Chem. Commun. 2005, 63-65. (b) Lee, S. I.; Park, S. Y.; Park, J. H.; Jung, I. G.; Choi, S. Y.; Chung, Y. K. J. Org. Chem. 2006, 71, 91-96.

(24) Herrmann, W. A.; Schütz, J.; Frey, G. D.; Herdtweck, E. Organometallics 2006, 25, 2437-2448, and references therein.

(25) Fürstner, A.; Seidel, G.; Kremzow, D.; Lehmann, C. W. Organometallics 2003, 22, 907-909.

(26) Ishikawa, T. Arkivoc 2006, vii, 148-168, and references therein.

(27) Steiner, G.; Kopacka, H.; Ongania, K.-H.; Wurst, K.; PreishuberPflügl, P.; Bildstein, B. Eur. J. Inorg. Chem. 2005, 1325-1333.
Table 3. Synthesis of $\mathbf{R h}-\mathrm{NHC}$ Complexes
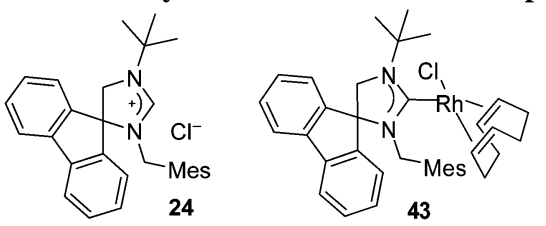

$54 \%$

2
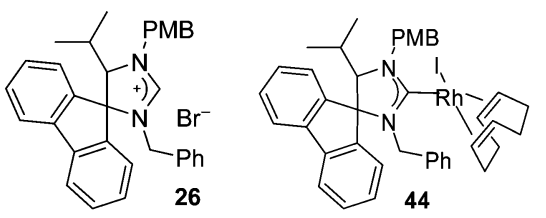

$81 \%$

(80:20)
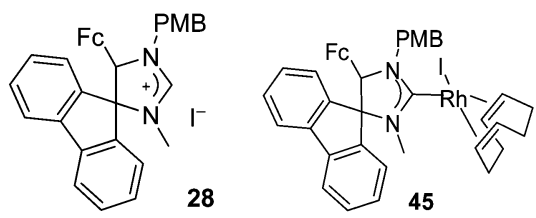

$82 \%$

(58:42)

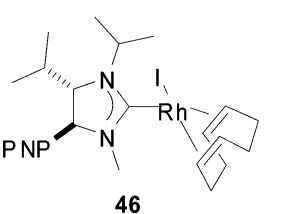

$79 \%$

(82:18)

4

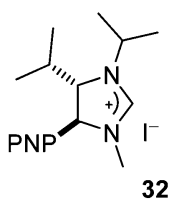

32
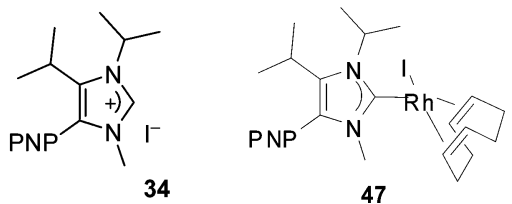

$46 \%$

${ }^{a}$ Isolated yields and ratios are reported. Ratios refer to relative amounts of rotamers. $\mathrm{Fc}=$ ferrocenyl.

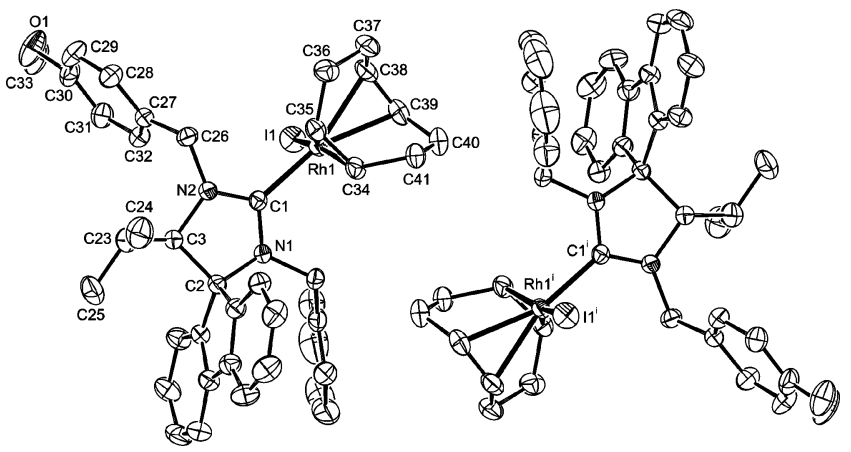

Figure 5. Displacement ellipsoid plot of two symmetry-related molecules in the high-temperature phase 44-I of the major isomer of $44(200 \mathrm{~K})$, drawn at the $50 \%$ probability level. Hydrogen atoms are omitted for clarity. Selected bond lengths $[\AA]$, angles [deg], and torsion angles [deg]: I1-Rh1 2.6748(3), Rh1-C1 2.023(3), N1-C1 1.351(3), N2-C1 1.342(3); I1-Rh1-C1 88.72(7), Rh1C1-N1 125.12(18), Rh1-C1-N2 126.67(19), N1-C1-N2 108.2(2); I1-Rh1-C1-N1 85.5(2), N2-C3-C23-C24-56.2(4), N2C3-C23-C25 176.3(3), N2-C26-C27-C28 157.8(3), C29C30-O1-C33 163.9(3). Symmetry operation i: $1-x, 1-y, 1-z$.

slight variations in the bond lengths and angles around the carbene center.

The ${ }^{13} \mathrm{C}_{\text {carbene }} \mathrm{NMR}$ chemical shifts (208-218 ppm) and $\mathrm{Rh}-$ $\mathrm{C}_{\text {carbene }}$ coupling constants $(43-47 \mathrm{~Hz})$ of our saturated $\mathrm{NHC}$ transition metal complexes are in good agreement with values reported for complexes of other saturated NHCs (Table 4, entries $1-11) .{ }^{15 a, 29}$ Furthermore, complex 47 shows a typical chemical

(28) (a) Karkhanis, D. W.; Field, L. Phosphorus Sulfur 1985, 22, 4957. (b) Marshall, C.; Ward, M. F.; Harrison, W. T. A. J. Organomet. Chem. 2005, 690, 3970-3975. 


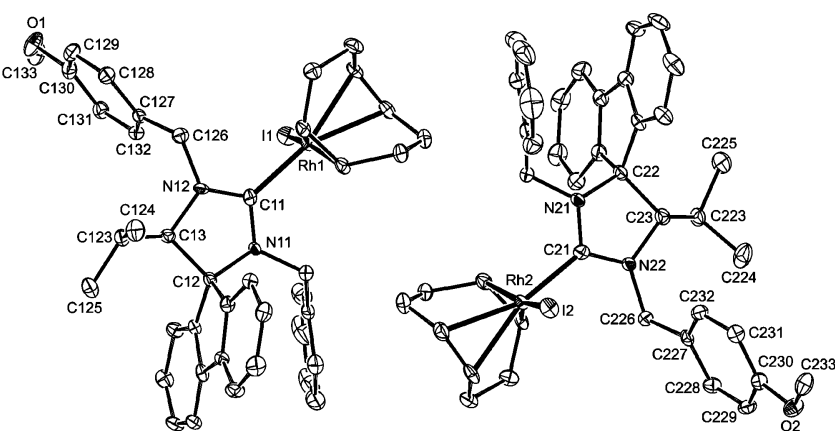

Figure 6. Displacement ellipsoid plot of the two independent molecules in the low-temperature phase 44-II of the major isomer of $44(110 \mathrm{~K})$ drawn at the $50 \%$ probability level. Hydrogen atoms are omitted for clarity. Selected bond lengths $[\AA ̊ \Omega]$, angles [deg], and torsion angles [deg]. Values for the second molecule are given in square brackets: I1-Rh1 2.6821(3) [2.6592(3)], Rh1-C11 2.020(3) [2.022(3)], N11-C11 1.346(4) [1.347(4)], N12-C11 1.337(4) [1.341(4)]; I1-Rh1-C11 89.01(9) [89.01(9)], Rh1-C11N11 125.5(2) [124.1(2)], Rh1-C11-N12 126.8(2) [126.7(2)], N11-C11-N12 107.6(3) [109.0(3)]; I1-Rh1-C11-N11 84.4(3) $[-88.2(3)], \mathrm{N} 12-\mathrm{C} 13-\mathrm{C} 123-\mathrm{C} 124-53.8(4)[-71.7(4)], \mathrm{N} 12-$ C13-C123-C125 179.3(3) [168.5(3)], N12-C126-C127-C128 159.2(3) [-165.9(3)], C129-C130-O1-C133 168.5(3) [-176.3(3)].

shift (180.0 ppm) for Rh complexes of imidazolin-2-ylidenes A (entry 12). ${ }^{24,30}$ However, recent studies have shown that chemical shifts of carbene carbons and the coupling constants $J(\mathrm{Rh}-\mathrm{C})$ in ${ }^{13} \mathrm{C} \mathrm{NMR}$, although usually specific for the type of carbon, do not show systematic order for an estimation of the $\sigma$ donor strength. ${ }^{24}$

The X-ray crystal structures of the NHC complexes all show (slightly disturbed) square-planar coordination geometries, as expected for $16 \mathrm{e} \mathrm{Rh}$ and $\mathrm{Ir}$ complexes. The different $\mathrm{Rh}$ complexes show only small differences in $\mathrm{Rh}-\mathrm{C}_{\text {carbene }}$ distances (Table 5, entries 1-5). However, the saturated NHC complexes show characteristic $\mathrm{N} 1-\mathrm{C} 1-\mathrm{N} 2$ angles around $108^{\circ}$ (entries $1-4$ ), which are $3-4^{\circ}$ larger than that in complex 47 (entry 5), bearing an unsaturated NHC. To accommodate the steric requirements of tert-butyl substituents in complexes 35, 38a, and $\mathbf{3 8 b}$, their $\mathrm{M}-\mathrm{C} 1-\mathrm{N} 2$ angles are about $10^{\circ}$ larger than their $\mathrm{M}-\mathrm{C} 1-\mathrm{N} 1$ angles (entries $1,6,7)$. When the two nitrogen substituents are sterically more alike, these angles are almost equal (entries 2-5). Furthermore, the plane of the fivemembered carbene ring is almost perpendicular to the coordination plane of the complex $\left(>85^{\circ}\right)$.

\section{Conclusion}

We have successfully applied the multicomponent synthesis of $2 \mathrm{H}$-2-imidazolines in the preparation of a range of unsymmetrically substituted imidazolidin-2-ylidene complexes under mild conditions. Substituents at N-1, N-3, C-4, and C-5 can be varied easily and independently by choosing the appropriate amine, aldehyde, isocyanide, or halide in the two-step synthesis of the NHC precursors. Deprotonation of the imidazolium salts with $\mathrm{KO}^{t} \mathrm{Bu}$ and direct complexation of the in situ-generated $\mathrm{NHCs}$ at room temperature affords $\mathrm{Rh}-$ and $\mathrm{Ir}-\mathrm{NHC}$ complexes. The existence and stability of two hindered rotamers of $\mathrm{M}(\mathrm{cod}) \mathrm{X}(\mathrm{NHC})$ complexes have been unambiguously proven

(29) Coleman, A. W.; Hitchcock, P. B.; Lappert, M. F.; Maskell, R. K.; Müller, J. H. J. Organomet. Chem. 1985, 296, 173-196.

(30) Herrmann, W. A.; Köcher, C.; Goossen, L. J.; Artus, G. R. J. Chem.-Eur. J. 1996, 2, 1627-1636. by the separation and X-ray crystal structure determination of two rotamers of Ir complex 38. Also 4-( $p$-nitrophenyl)imidazoles, which are side products of reactions between amines, aldehydes, and $p$-nitrobenzyl isocyanide $\mathbf{1 8}$, can be used in the synthesis of NHC complexes. Data obtained from NMR spectroscopic and X-ray crystallographic studies of the complexes correspond well with earlier reported properties of NHCs.

\section{Experimental Section}

General Information. All reactions were carried out under an inert atmosphere of argon or dry nitrogen (glovebox). Standard syringe techniques were applied for transfer of air-sensitive reagents and dry solvents. Melting points were measured using a Stuart Scientific SMP3 melting point apparatus and are uncorrected. Infrared (IR) spectra were obtained from $\mathrm{CHCl}_{3}$ films on $\mathrm{NaCl}$ tablets (unless noted otherwise), using a Matteson Instruments 6030 Galaxy Series FT-IR spectrophotometer, and wavelengths $(v)$ are reported in $\mathrm{cm}^{-1} .{ }^{1} \mathrm{H}$ and ${ }^{13} \mathrm{C}$ nuclear magnetic resonance (NMR) spectra were recorded on a Bruker Avance 400 (400.13 and 100.61 $\mathrm{MHz}$, respectively), a Bruker Avance $250(250.13$ and $62.90 \mathrm{MHz}$, respectively), or a Bruker Avance $200(200.13$ and $50.32 \mathrm{MHz}$, respectively) with chemical shifts $(\delta)$ reported in ppm downfield from tetramethylsilane. Peak assignment was also done with the aid of gs-COSY, gs-HMQC, and gs-HMBC measurements. EIMS and HRMS spectral data were recorded on a Finnigan Mat 900 spectrometer. ESIMS and HRMS spectra were recorded on a LTQ XL Orbitrap spectrometer. Chromatographic purification refers to flash chromatography using the indicated solvent (mixture) and Baker 7024-02 silica gel (40 $\mu \mathrm{m}, 60 \AA$ ). Thin-layer chromatography was performed using silica plates from Merck (Kieselgel $60 \mathrm{~F}_{254}$ ) on aluminum with fluorescence indicator. Compounds on TLC were visualized by UV detection. THF and $\mathrm{Et}_{2} \mathrm{O}$ were dried and distilled from sodium benzophenone ketyl prior to use. DCM was dried and distilled from $\mathrm{CaH}_{2}$ prior to use. Petroleum ether (PE) with a boiling range of $40-65{ }^{\circ} \mathrm{C}$ was distilled prior to use as eluent for chromatography. Isocyanides $\mathbf{1 6}, \mathbf{1 7}$, and $\mathbf{1 8},{ }^{13}[\mathrm{Rh}(\operatorname{cod}) \mathrm{Cl}]_{2},{ }^{31}$ and $[\mathrm{Ir}(\mathrm{cod}) \mathrm{Cl}]_{2}{ }^{32}$ as well as imidazolines $\mathbf{2 5},{ }^{16 \mathrm{a}} \mathbf{2 9},{ }^{16 \mathrm{~b}} \mathbf{3 1},{ }^{16 \mathrm{~b}}$ and $\mathbf{3 3}{ }^{16 \mathrm{~b}}$ were prepared according to literature procedures. Other commercially available reagents were used as purchased.

Microwave Experiments. Microwave-assisted reactions were performed in a Discover (CEM Corporation) single-mode microwave instrument producing controlled irradiation at $2450 \mathrm{MHz}$, using standard sealed microwave glass vials. Reaction temperatures were monitored with an IR sensor on the outside wall of the reaction vials. Reaction times refer to hold times at the indicated temperatures, not to total irradiation times.

General Procedure I for the Synthesis of 2-Imidazolines. Reactions were carried out at a concentration of $1 \mathrm{M}$ amine, $1 \mathrm{M}$ aldehyde, and $0.5 \mathrm{M}$ isocyanide in dry DCM, unless noted otherwise. $\mathrm{Na}_{2} \mathrm{SO}_{4}$ and the aldehyde were added, at rt, to a stirred solution of the amine. After the mixture was stirred for $2 \mathrm{~h}$, the isocyanide was added and the reaction mixture was stirred at $\mathrm{rt}$ for an additional $18 \mathrm{~h}$. The reaction mixture was filtered and concentrated in vacuo. The crude product was purified by flash column chromatography $\left(\mathrm{PE} / \mathrm{EtOAc} / \mathrm{Et}_{3} \mathrm{~N}=2: 1: 0.01\right.$, gradient, unless stated otherwise).

2-Imidazoline 22. According to General Procedure I, reaction between tert-butylamine $\mathbf{1 0}$ (1.46 g, $20 \mathrm{mmol}), p$-formaldehyde $\mathbf{1 3}$ (600 $\mathrm{mg}, 20.0 \mathrm{mmol})$, and isocyanide $16(2.0 \mathrm{~g}, 10.5 \mathrm{mmol})$, followed by flash column chromatography, afforded 22 (2.58 g, $89 \%$ ) as a light yellow solid. Crystallization from pentane/ $/ \mathrm{t}_{2} \mathrm{O}$ affords white crystals. Mp: 95-96 ${ }^{\circ} \mathrm{C} .{ }^{1} \mathrm{H}$ NMR $(250 \mathrm{MHz}$, $\left.\mathrm{CDCl}_{3}\right): \delta(\mathrm{ppm}) 7.68(\mathrm{~d}, J=6.9 \mathrm{~Hz}, 2 \mathrm{H}), 7.50-7.32(\mathrm{~m}, 7 \mathrm{H})$, $3.73(\mathrm{~s}, 2 \mathrm{H}), 1.42(\mathrm{~s}, 9 \mathrm{H}) .{ }^{13} \mathrm{C} \mathrm{NMR}\left(63 \mathrm{MHz}, \mathrm{CDCl}_{3}\right): \delta(\mathrm{ppm})$ $155.6(\mathrm{CH}), 150.6(2 \times \mathrm{C}), 140.3(2 \times \mathrm{C}), 128.7(2 \times \mathrm{CH}), 128.4$ $(2 \times \mathrm{CH}), 124.2(2 \times \mathrm{CH}), 120.1(2 \times \mathrm{CH}), 79.1(\mathrm{C}), 55.6\left(\mathrm{CH}_{2}\right), 53.1$ 
Table 4. ${ }^{13} \mathrm{C}$ NMR Chemical Shifts $\delta$ of $\mathrm{M}(\operatorname{cod}) \mathrm{X}(\mathrm{NHC})$ Complexes and $\mathrm{Rh}-\mathrm{C}_{\text {carbene }}$ Coupling Constants $J$ of $\mathrm{Rh}(\operatorname{cod}) \mathrm{X}(\mathrm{NHC})$ Complexes $^{a}$

\begin{tabular}{ccllc}
\hline entry & complex & $\mathrm{M}$ & $\mathrm{X}$ & $\delta \mathrm{C}_{\text {carbene }}(\mathrm{ppm})$ \\
\hline 1 & $\mathbf{3 5}$ & $\mathrm{Rh}$ & $\mathrm{I}$ & 213.3 \\
2 & $\mathbf{3 6}$ & $\mathrm{Ir}$ & $\mathrm{I}$ & 209.0 \\
3 & $\mathbf{3 7}$ & $\mathrm{Rh}$ & $\mathrm{I}$ & 213.3 \\
4 & $\mathbf{3 8 a}$ & $\mathrm{Ir}$ & $\mathrm{I}$ & 208.8 \\
5 & $\mathbf{3 8 b}$ & $\mathrm{Ir}$ & $\mathrm{I}$ & 209.2 \\
6 & $\mathbf{4 0}$ & $\mathrm{Rh}$ & $\mathrm{Cl}$ & 213.8 \\
7 & $\mathbf{4 2}$ & $\mathrm{Rh}$ & $\mathrm{Cl}$ & 214.0 \\
8 & $\mathbf{4 3}$ & $\mathrm{Rh}$ & $\mathrm{Cl}$ & 217.8 \\
9 & $\mathbf{4 4}$ & $\mathrm{Rh}$ & $\mathrm{I}$ & 217.8 \\
10 & $\mathbf{4 5}^{b}$ & $\mathrm{Rh}$ & $\mathrm{I}$ & 216.4 \\
11 & $\mathbf{4 6}^{b}$ & $\mathrm{Rh}$ & $\mathrm{I}$ & 213.7 \\
12 & $\mathbf{4 7}^{b}$ & $\mathrm{Rh}$ & $\mathrm{I}$ & 45.9
\end{tabular}

${ }^{a}$ Spectra were recorded in $\mathrm{CDCl}_{3} .{ }^{b} \mathrm{Chemical}$ shifts and coupling constants of main isomer are reported.

Table 5. Selected Bond Distances (̊̊), Bond Angles (deg), and Torsion Angles (deg) for M(cod)I(NHC) Complexes

\begin{tabular}{|c|c|c|c|c|c|c|c|}
\hline entry & complex & M & $\mathrm{M}-\mathrm{C} 1$ & $\mathrm{~N} 1-\mathrm{C} 1-\mathrm{N} 2$ & $\mathrm{M}-\mathrm{C} 1-\mathrm{N} 1$ & $\mathrm{M}-\mathrm{C} 1-\mathrm{N} 2$ & $\mathrm{I}-\mathrm{M}-\mathrm{C} 1-\mathrm{N} 1$ \\
\hline 1 & 35 & $\mathrm{Rh}$ & $2.0197(14)$ & $107.88(12)$ & $120.53(10)$ & $131.58(10)$ & $-85.36(11)$ \\
\hline 2 & $44 I$ & $\mathrm{Rh}$ & $2.023(3)$ & $108.2(2)$ & $125.12(18)$ & $126.67(19)$ & $85.5(2)$ \\
\hline \multirow{2}{*}{3} & $44-\mathrm{II}^{a}$ & $\mathrm{Rh}$ & $2.020(3)$ & $107.6(3)$ & $125.5(2)$ & $126.8(2)$ & $84.4(3)$ \\
\hline & & & $2.022(3)$ & $109.0(3)$ & $124.1(2)$ & $126.7(2)$ & $-88.2(3)$ \\
\hline 4 & 46 & $\mathrm{Rh}$ & $2.0183(15)$ & $108.57(13)$ & $125.59(11)$ & $125.78(10)$ & $88.22(13)$ \\
\hline 5 & 47 & $\mathrm{Rh}$ & $2.028(2)$ & 104.84(17) & $128.43(15)$ & $126.72(14)$ & $90.56(18)$ \\
\hline 6 & $38 \mathrm{a}$ & Ir & $2.023(2)$ & $108.48(19)$ & $121.82(15)$ & $129.69(16)$ & $89.20(17)$ \\
\hline 7 & $38 \mathrm{~b}$ & $\mathrm{Ir}$ & $2.030(3)$ & $108.2(2)$ & $121.34(18)$ & $129.94(19)$ & $86.9(2)$ \\
\hline
\end{tabular}

${ }^{a}$ Values of both molecules in the asymmetric unit are reported.

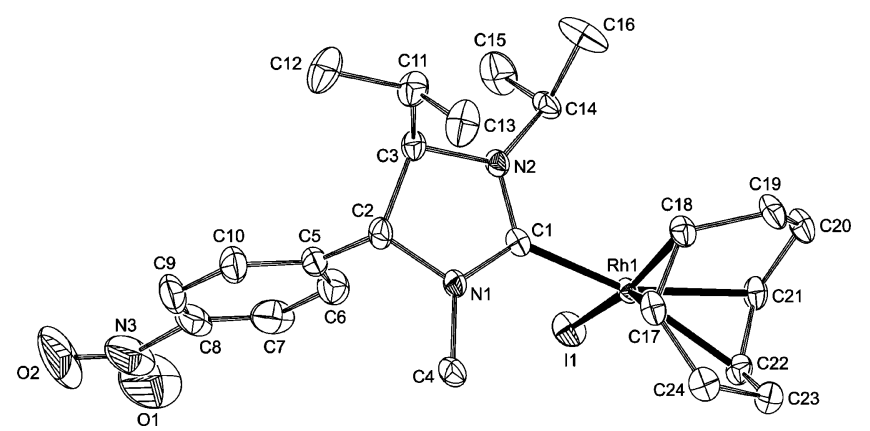

Figure 7. Displacement ellipsoid plot of the major isomer of $\mathbf{4 6}$ drawn at the $50 \%$ probability level. Hydrogen atoms and disordered solvent molecules are omitted for clarity. Selected bond lengths [A], angles [deg], and torsion angles [deg]: I1-Rh1 2.68360(17), Rh1-C1 2.0183(15), N1-C1 1.3473(18), N2-C1 1.339(2); I1Rh1-C1 88.86(4), Rh1-C1-N1 125.59(11), Rh1-C1-N2 125.78(10), N1-C1-N2 108.57(13); I1-Rh1-C1-N1 88.22(13).

(C), $28.9\left(3 \times \mathrm{CH}_{3}\right)$. IR (neat): $2973(\mathrm{~s}), 1674(\mathrm{~m}), 1585$ (s), 1450 (s), 1236 (s). HRMS (EI, $70 \mathrm{eV}$ ): calcd for $\mathrm{C}_{19} \mathrm{H}_{20} \mathrm{~N}_{2}\left(\mathrm{M}^{+}\right)$ 276.1626, found 276.1617. Anal. Calcd for $\mathrm{C}_{19} \mathrm{H}_{20} \mathrm{~N}_{2}(\%)$ : C 82.57, H 7.29, N 10.14. Found: C 82.42, H 7.44, N 10.06.

General Procedure II for the Synthesis of 2-Imidazolinium Salts. Reactions were carried out at a concentration of $0.15-0.25$ $\mathrm{M}$ of imidazoline in dry DCM, unless noted otherwise. The halide was added to a stirred solution of the imidazoline, and the reaction mixture was stirred at $\mathrm{rt}$ for $18 \mathrm{~h}$. Then, the reaction mixture was concentrated in vacuo. The crude product was washed with pentane or $\mathrm{Et}_{2} \mathrm{O}$.

2-Imidazolinium Iodide 23. According to General Procedure II, alkylation of imidazoline 22 (1.99 g, $7.2 \mathrm{mmol})$ with methyl iodide 19 (1.08 g, $7.6 \mathrm{mmol}$ ) followed by washing with $\mathrm{Et}_{2} \mathrm{O}$ afforded salt 23 as a white solid $(2.95 \mathrm{~g}, 98 \%) .{ }^{1} \mathrm{H}$ NMR $(250 \mathrm{MHz}$, $\left.\mathrm{CDCl}_{3}\right): \delta(\mathrm{ppm}) 7.75-7.70(\mathrm{~m}, 4 \mathrm{H}), 7.57-7.43(\mathrm{~m}, 4 \mathrm{H}), 4.26(\mathrm{~s}$, 2H), $2.91(\mathrm{~s}, 3 \mathrm{H}), 1.69$ (s, 9H). ${ }^{13} \mathrm{C}$ NMR $\left(50 \mathrm{MHz}, \mathrm{CDCl}_{3}\right): \delta$ (ppm) $157.2(\mathrm{CH}), 141.7(2 \times \mathrm{C}), 140.2(2 \times \mathrm{C}), 131.1(2 \times \mathrm{CH})$, $129.4(2 \times \mathrm{CH}), 124.3(2 \times \mathrm{CH}), 120.7(2 \times \mathrm{CH}), 74.8(\mathrm{C}), 57.9(\mathrm{C})$, $56.6\left(\mathrm{CH}_{2}\right), 30.7\left(\mathrm{CH}_{3}\right), 28.2\left(3 \times \mathrm{CH}_{3}\right)$. IR (neat): $1633(\mathrm{~s}), 1450$

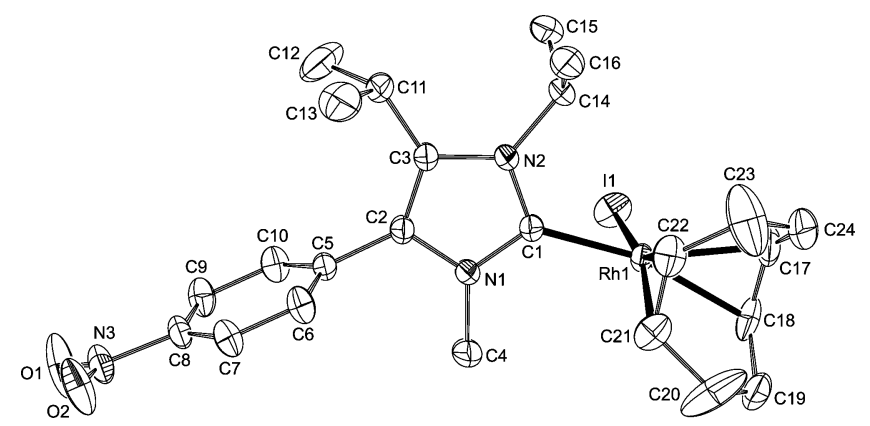

Figure 8. Displacement ellipsoid plot of $\mathbf{4 7}$ drawn at the $50 \%$ probability level. Hydrogen atoms are omitted for clarity. Selected bond lengths $[\AA]$, angles [deg], and torsion angles [deg]: I1-Rh1 2.6652(2), Rh1-C1 2.028(2), N1-C1 1.348(3), N2-C1 1.360(3); I1-Rh1-C1 87.58(6), Rh1-C1-N1 128.43(15), Rh1-C1-N2 126.72(14), N1-C1-N2 104.84(17); I1-Rh1-C1-N1 90.56(18).

(m), 1307 (m), 1269 (m). HRMS (ESI): calcd for $\mathrm{C}_{20} \mathrm{H}_{23} \mathrm{~N}_{2}{ }^{+}$ (cation) 291.1856, found 276.1856.

2-Imidazolinium Iodide 24. According to General Procedure II, alkylation of imidazoline $22(770 \mathrm{mg}, 2.8 \mathrm{mmol})$ with 2,4,6trimethylbenzyl chloride 21 (475 mg, $2.8 \mathrm{mmol}$ ) in DMF (15 mL), followed by washing with pentane, afforded $24(1.04 \mathrm{~g}, 84 \%)$ as a white solid. ${ }^{1} \mathrm{H}$ NMR $\left(250 \mathrm{MHz}, \mathrm{CDCl}_{3}\right): \delta(\mathrm{ppm}) 10.44(\mathrm{~s}, 1 \mathrm{H})$, $7.60(\mathrm{~d}, J=7.5 \mathrm{~Hz}, 2 \mathrm{H}), 7.52(\mathrm{~d}, J=7.6 \mathrm{~Hz}, 2 \mathrm{H}), 7.45-7.38(\mathrm{~m}$, 2H), 7.28-7.23 (m, 2H), 6.45 (s, 2H), 4.78 (s, 2H), 4.23 (s, 2H), 2.09 (s, 3H), $1.92(\mathrm{~s}, 6 \mathrm{H}), 1.67(\mathrm{~s}, 9 \mathrm{H}) ;{ }^{13} \mathrm{C}$ NMR $(63 \mathrm{MHz}$, $\left.\mathrm{CDCl}_{3}\right): \delta(\mathrm{ppm}) 158.6(\mathrm{CH}), 142.2(2 \times \mathrm{C}), 139.9(2 \times \mathrm{C}), 137.9$ (C), $137.6(2 \times \mathrm{C}), 130.5(2 \times \mathrm{CH}), 129.1(2 \times \mathrm{CH}), 128.9(2 \times \mathrm{CH})$, $126.3(\mathrm{C}), 124.0(2 \times \mathrm{CH}), 120.4(2 \times \mathrm{CH}), 74.5(\mathrm{C}), 58.0\left(\mathrm{CH}_{2}\right)$, $57.8(\mathrm{C}), 44.6\left(\mathrm{CH}_{2}\right), 28.3\left(3 \times \mathrm{CH}_{3}\right), 20.7\left(\mathrm{CH}_{3}\right), 19.7\left(2 \times \mathrm{CH}_{3}\right)$. IR (neat): $1626(\mathrm{~s}), 1450(\mathrm{~m}), 1217(\mathrm{~m})$. HRMS (ESI): calcd for $\mathrm{C}_{29} \mathrm{H}_{33} \mathrm{~N}_{2}{ }^{+}$(cation) 409.2638, found 409.2631.

2-Imidazolinium Bromide 26. According to General Procedure II, alkylation of imidazoline 25 (1.4 g, $3.7 \mathrm{mmol})$ with benzyl bromide 20 (751 mg, $4.4 \mathrm{mmol})$, followed by washing with cold $\mathrm{Et}_{2} \mathrm{O}$, afforded $26(1.9 \mathrm{~g}, 93 \%)$ as a white solid. ${ }^{1} \mathrm{H}$ NMR $(250$ $\left.\mathrm{MHz}, \mathrm{CDCl}_{3}\right): \delta(\mathrm{ppm}) 10.50(\mathrm{~s}, 1 \mathrm{H}), 7.71(\mathrm{~d}, J=7.5 \mathrm{~Hz}, 1 \mathrm{H})$, $7.62(\mathrm{~d}, J=7.6 \mathrm{~Hz}, 1 \mathrm{H}), 7.56-7.35(\mathrm{~m}, 5 \mathrm{H}), 7.29-7.20(\mathrm{~m}, 1 \mathrm{H})$, 
$7.18-6.97(\mathrm{~m}, 7 \mathrm{H}), 6.90-6.87(\mathrm{~m}, 2 \mathrm{H}), 5.37(\mathrm{~d}, J=14.4 \mathrm{~Hz}$, $1 \mathrm{H}), 4.72(\mathrm{~d}, J=14.4 \mathrm{~Hz}, 1 \mathrm{H}), 4.32(\mathrm{~d}, J=5.3 \mathrm{~Hz}, 1 \mathrm{H}), 4.30(\mathrm{~d}$, $J=14.4 \mathrm{~Hz}, 1 \mathrm{H}), 4.06(\mathrm{~d}, J=14.4 \mathrm{~Hz}, 1 \mathrm{H}), 3.86$ (s, 3H), 2.19$2.13(\mathrm{~m}, 1 \mathrm{H}), 0.77(\mathrm{~d}, J=6.9 \mathrm{~Hz}, 3 \mathrm{H}), 0.60(\mathrm{~d}, J=7.0 \mathrm{~Hz}, 3 \mathrm{H})$. ${ }^{13} \mathrm{C} \mathrm{NMR}\left(63 \mathrm{MHz}, \mathrm{CDCl}_{3}\right): \delta(\mathrm{ppm}) 160.9(\mathrm{CH}), 160.1(\mathrm{C}), 143.1$ (C), $141.5(\mathrm{C}), 140.1(\mathrm{C}), 137.9(\mathrm{C}), 133.2(\mathrm{C}), 131.0(\mathrm{CH}), 130.6$ $(\mathrm{CH}), 130.4(2 \times \mathrm{CH}), 129.1(2 \times \mathrm{CH}), 129.0(\mathrm{CH}), 128.5(2 \times \mathrm{CH})$, $128.4(\mathrm{CH}), 127.9(\mathrm{CH}), 127.4(\mathrm{CH}), 125.3(\mathrm{CH}), 124.6(\mathrm{C}), 120.7$ $(\mathrm{CH}), 120.2(\mathrm{CH}), 114.7(2 \times \mathrm{CH}), 79.2(\mathrm{C}), 74.2(\mathrm{CH}), 55.4\left(\mathrm{CH}_{3}\right)$, $51.8\left(\mathrm{CH}_{2}\right), 49.3\left(\mathrm{CH}_{2}\right), 28.0(\mathrm{CH}), 19.3\left(\mathrm{CH}_{3}\right), 18.6\left(\mathrm{CH}_{3}\right)$. IR (neat): 1626 (s), $1514(\mathrm{~m}), 1452$ (m), 1252 (m). HRMS (ESI): calcd for $\mathrm{C}_{33} \mathrm{H}_{33} \mathrm{~N}_{2} \mathrm{O}^{+}$(cation) 473.2587, found 473.2581.

2-Imidazoline 27. According to General Procedure I, reaction between $p$-methoxybenzylamine $\mathbf{1 1}(685 \mathrm{mg}, 5.0 \mathrm{mmol})$, ferrocenecarboxaldehyde $\mathbf{1 5}(1.07 \mathrm{~g}, 5.0 \mathrm{mmol})$, and isocyanide $\mathbf{1 6}$ (500 $\mathrm{mg}, 2.6 \mathrm{mmol})$ in $\mathrm{MeOH}(15 \mathrm{~mL})$, followed by flash column chromatography, afforded 27 (936 $\mathrm{mg} \mathrm{69 \% )} \mathrm{as} \mathrm{an} \mathrm{orange} \mathrm{solid.}$ ${ }^{1} \mathrm{H} \mathrm{NMR}\left(250 \mathrm{MHz}, \mathrm{CDCl}_{3}\right): \delta$ (ppm) 7.67-7.63 (m, 1H), 7.54$7.31(\mathrm{~m}, 7 \mathrm{H}), 7.23-7.17(\mathrm{~m}, 1 \mathrm{H}), 7.11-6.96(\mathrm{~m}, 4 \mathrm{H}), 4.98(\mathrm{~d}, J$ $=14.5 \mathrm{~Hz}, 1 \mathrm{H}), 4.95(\mathrm{~s}, 1 \mathrm{H}), 4.50(\mathrm{~d}, J=14.5 \mathrm{~Hz}, 1 \mathrm{H}), 4.14(\mathrm{br}$ s, $1 \mathrm{H}), 3.95($ br s, $1 \mathrm{H}), 3.92(\mathrm{~s}, 3 \mathrm{H}), 3.90(\mathrm{~s}, 5 \mathrm{H}), 3.77(\mathrm{br} \mathrm{s}, 1 \mathrm{H})$, $3.13(\mathrm{~d}, J=1.1 \mathrm{~Hz}, 1 \mathrm{H}) .{ }^{13} \mathrm{C} \mathrm{NMR}\left(63 \mathrm{MHz}, \mathrm{CDCl}_{3}\right): \delta(\mathrm{ppm})$ $159.3(\mathrm{C}), 159.1(\mathrm{CH}), 149.6(\mathrm{C}), 145.7$ (C), $141.4(\mathrm{C}), 139.9$ (C), $129.2(2 \times \mathrm{CH}), 129.1(\mathrm{C}), 128.5(\mathrm{CH}), 128.0(\mathrm{CH}), 127.7(\mathrm{CH})$, $126.7(\mathrm{CH}), 126.0(\mathrm{CH}), 124.4(\mathrm{CH}), 119.5(\mathrm{CH}), 119.1(\mathrm{CH}), 114.5$ $(2 \times \mathrm{CH}), 85.0(\mathrm{C}), 84.1(\mathrm{C}), 69.4(\mathrm{CH}), 66.5(5 \times \mathrm{CH}), 67.8(\mathrm{CH})$, $66.9(\mathrm{CH}), 66.3(\mathrm{CH}), 65.1(\mathrm{CH}), 55.4\left(\mathrm{CH}_{3}\right), 50.2\left(\mathrm{CH}_{2}\right)$. IR (neat): 1599 (s), 1512 (s), 1448 (m), 1248 (s). HRMS (EI, 70 eV): calcd for $\mathrm{C}_{33} \mathrm{H}_{28} \mathrm{FeN}_{2} \mathrm{O}\left(\mathrm{M}^{+}\right)$524.1551, found 524.1533.

2-Imidazolinium Iodide 28. According to General Procedure II, alkylation of imidazoline 27 (380 mg, $0.73 \mathrm{mmol}$ ) with methyl iodide 19 (109 mg, $0.77 \mathrm{mmol}$ ) followed by washing with pentane afforded salt 28 (481 mg, 99\%) as a light brown solid. ${ }^{1} \mathrm{H}$ NMR $\left(250 \mathrm{MHz}, \mathrm{CDCl}_{3}\right): \delta(\mathrm{ppm}) 9.10(\mathrm{~s}, 1 \mathrm{H}), 8.23-8.20(\mathrm{~m}, 1 \mathrm{H})$, $7.69(\mathrm{~d}, J=8.6 \mathrm{~Hz}, 2 \mathrm{H}), 7.68-7.37(\mathrm{~m}, 6 \mathrm{H}), 7.20-7.09(\mathrm{~m}, 1 \mathrm{H})$, $7.06(\mathrm{~d}, J=8.6 \mathrm{~Hz}, 2 \mathrm{H}), 5.65(\mathrm{~s}, 1 \mathrm{H}), 5.21(\mathrm{~d}, J=13.6 \mathrm{~Hz}, 1 \mathrm{H})$, $5.17(\mathrm{~d}, J=13.8 \mathrm{~Hz}, 1 \mathrm{H}), 4.26-4.25(\mathrm{~m}, 1 \mathrm{H}), 4.17-4.16(\mathrm{~m}$, 1H), 3.96-3.94 (m, 1H), 3.92 (s, 5H), 3.89 (s, 3H), 3.21-3.20 (m, 1H), $2.70(\mathrm{~s}, 3 \mathrm{H}) \cdot{ }^{13} \mathrm{C} \mathrm{NMR}\left(63 \mathrm{MHz}, \mathrm{CDCl}_{3}\right): \delta(\mathrm{ppm}) 160.2$ (C), $159.3(\mathrm{CH}), 141.4(\mathrm{C}), 141.2(\mathrm{C}), 140.9(\mathrm{C}), 138.3(\mathrm{C}), 131.2$ $(\mathrm{CH}), 131.0(2 \times \mathrm{CH}), 130.8(\mathrm{CH}), 129.5(\mathrm{CH}), 127.7(\mathrm{CH}), 126.5$ $(\mathrm{CH}), 126.0(\mathrm{CH}), 125.4(\mathrm{C}), 120.4(\mathrm{CH}), 120.3(\mathrm{CH}), 114.9$ $(2 \times \mathrm{CH}), 80.0(\mathrm{C}), 78.3(\mathrm{C}), 72.3(\mathrm{CH}), 69.2(5 \times \mathrm{CH}), 68.5(\mathrm{CH})$, $68.2(\mathrm{CH}), 68.1(\mathrm{CH}), 66.0(\mathrm{CH}), 55.4\left(\mathrm{CH}_{3}\right) 50.3\left(\mathrm{CH}_{2}\right), 31.3$ $\left(\mathrm{CH}_{3}\right)$. IR (neat): 1639 (s), $1514(\mathrm{~m}), 1250$ (s). HRMS (ESI): calcd for $\mathrm{C}_{34} \mathrm{H}_{31} \mathrm{FeN}_{2} \mathrm{O}^{+}$(cation) 539.1780, found 539.1772.

2-Imidazolinium Iodide 30. According to General Procedure II, alkylation of imidazoline 29 (1.28 g, $4.9 \mathrm{mmol})$ with methyl iodide 19 (734 mg, $5.17 \mathrm{mmol}$ ) followed by washing with pentane afforded salt $30(1.8 \mathrm{~g}, 93 \%)$ as a white solid. ${ }^{1} \mathrm{H}$ NMR (400 MHz, $\left.\mathrm{CDCl}_{3}\right): \quad \delta(\mathrm{ppm}) 9.73(\mathrm{~s}, 1 \mathrm{H}), 7.51-7.46(\mathrm{~m}, 3 \mathrm{H}),, 7.37-7.36$ $(\mathrm{m}, 2 \mathrm{H}), 4.80(\mathrm{~d}, J=12.2 \mathrm{~Hz}, 1 \mathrm{H}), 4.01(\mathrm{~s}, 3 \mathrm{H}), 3.94(\mathrm{~d}, J=12.2$ $\mathrm{Hz}, 1 \mathrm{H}), 3.43$ (s, 3H), 1.58 (s, 9H). ${ }^{13} \mathrm{C} \mathrm{NMR}\left(101 \mathrm{MHz}, \mathrm{CDCl}_{3}\right)$ : $\delta(\mathrm{ppm}) 168.9(\mathrm{C}), 156.6(\mathrm{CH}), 134.0(\mathrm{C}), 130.1(\mathrm{CH}), 129.8$ $(2 \times \mathrm{CH}), 126.4(2 \times \mathrm{CH}), 75.9(\mathrm{C}), 58.1(\mathrm{C}), 57.7\left(\mathrm{CH}_{2}\right), 54.1\left(\mathrm{CH}_{3}\right)$, $33.8\left(\mathrm{CH}_{3}\right), 28.1\left(3 \times \mathrm{CH}_{3}\right)$. IR (neat): 2974 (s), 1743 (s), 1633 (s), 1265 (s), 1230 (s), 1196 (s). HRMS (ESI): calcd for $\mathrm{C}_{16} \mathrm{H}_{23} \mathrm{~N}_{2} \mathrm{O}_{2}{ }^{+}$ (cation) 275.1754, found 275.1754.

2-Imidazolinium Iodide 32. According to General Procedure II, alkylation of imidazoline $\mathbf{3 1}(500 \mathrm{mg}, 1.8 \mathrm{mmol})$ with methyl iodide 19 (284 mg, $2.0 \mathrm{mmol}$ ) followed by washing with $\mathrm{Et}_{2} \mathrm{O}$ afforded salt $32(656 \mathrm{mg}, 86 \%)$ as a white solid. ${ }^{1} \mathrm{H}$ NMR (250 MHz, DMSO- $\left.d_{6}\right): \delta(\mathrm{ppm}) 8.77(\mathrm{~s}, 1 \mathrm{H}), 8.34(\mathrm{~d}, J=8.2 \mathrm{~Hz}, 2 \mathrm{H})$, $7.73(\mathrm{~d}, J=8.3 \mathrm{~Hz}, 2 \mathrm{H}), 5.34(\mathrm{~d}, J=4.6 \mathrm{~Hz}, 1 \mathrm{H}), 4.26-4.11(\mathrm{~m}$, $1 \mathrm{H}), 3.64-3.53(\mathrm{~m}, 1 \mathrm{H}), 2.94(\mathrm{~s}, 3 \mathrm{H}), 2.60-2.39(\mathrm{~m}, 1 \mathrm{H}), 1.43$ $(\mathrm{d}, J=4.8 \mathrm{~Hz}, 3 \mathrm{H}), 1.27(\mathrm{~d}, J=4.7 \mathrm{~Hz}, 3 \mathrm{H}), 0.92(\mathrm{~d}, J=4.4 \mathrm{~Hz}$, $6 \mathrm{H}) .{ }^{13} \mathrm{C}$ NMR (63 MHz, DMSO- $\left.d_{6}\right): \delta(\mathrm{ppm}) 156.3(\mathrm{CH}), 147.9$
(C), $144.5(\mathrm{C}), 128.7(2 \times \mathrm{CH}), 124.4(2 \times \mathrm{CH}), 72.4(\mathrm{CH}), 63.4$ $(\mathrm{CH}), 47.7(\mathrm{CH}), 32.6\left(\mathrm{CH}_{3}\right), 27.4(\mathrm{CH}), 21.2\left(\mathrm{CH}_{3}\right), 20.7\left(\mathrm{CH}_{3}\right)$,$16.7\left(\mathrm{CH}_{3}\right), 13.8\left(\mathrm{CH}_{3}\right)$. IR (KBr): $1743(\mathrm{~s}), 1633(\mathrm{~s}), 1265(\mathrm{~m})$, $1230(\mathrm{~m}), 1196(\mathrm{~m})$. HRMS (ESI): calcd for $\mathrm{C}_{16} \mathrm{H}_{24} \mathrm{~N}_{3} \mathrm{O}_{2}{ }^{+}$(cation) 290.1863 , found 290.1863 .

2-Imidazolium Iodide 34. Methyl iodide 19 (988 mg, $7.0 \mathrm{mmol})$ was added to a solution of imidazole $\mathbf{3 3}(238 \mathrm{mg}, 2.8 \mathrm{mmol})$ in DCM $(4 \mathrm{~mL})$ in a microwave vessel. The reaction mixture was heated in the microwave at $100{ }^{\circ} \mathrm{C}$ for $20 \mathrm{~min}$. After cooling, the reaction mixture was concentrated in vacuo. After washing with $\mathrm{Et}_{2} \mathrm{O}$, salt $34(253 \mathrm{mg}, 70 \%)$ was isolated as a white solid. ${ }^{1} \mathrm{H}$ NMR $\left(250 \mathrm{MHz}, \mathrm{CDCl}_{3}\right): \delta(\mathrm{ppm}) 10.38(\mathrm{~s}, 1 \mathrm{H}), 8.41(\mathrm{~d}, J=8.6 \mathrm{~Hz}$, $2 \mathrm{H}), 7.80(\mathrm{~d}, J=8.6 \mathrm{~Hz}, 2 \mathrm{H}), 4.68-4.62(\mathrm{~m}, 1 \mathrm{H}), 3.82(\mathrm{~s}, 3 \mathrm{H})$, $3.15-3.11(\mathrm{~m}, 1 \mathrm{H}), 1.82(\mathrm{~d}, J=6.7 \mathrm{~Hz}, 6 \mathrm{H}), 1.22(\mathrm{~d}, J=7.1 \mathrm{~Hz}$, $6 \mathrm{H}) .{ }^{13} \mathrm{C} \mathrm{NMR}\left(63 \mathrm{MHz}, \mathrm{CDCl}_{3}\right)$ : $\delta$ (ppm) $149.2(\mathrm{C}), 136.5(\mathrm{C})$, $135.7(\mathrm{CH}), 132.9(2 \times \mathrm{CH}), 132.4(\mathrm{C}), 128.3(\mathrm{C}), 124.2(2 \times \mathrm{CH})$, $51.1(\mathrm{CH}), 35.2\left(\mathrm{CH}_{3}\right), 24.7(\mathrm{CH}), 24.0\left(2 \times \mathrm{CH}_{3}\right), 22.1\left(2 \times \mathrm{CH}_{3}\right)$. IR (neat): 1522 (s), 1348 (s). HRMS (ESI): calcd for $\mathrm{C}_{16} \mathrm{H}_{22} \mathrm{~N}_{3} \mathrm{O}_{2}{ }^{+}$ (cation) 288.1707, found 288.1707.

General Procedure III for the Synthesis of M(cod)X(NHC) Complexes. In a glovebox, $\mathrm{NaH}(12 \mathrm{mg}, 0.5 \mathrm{mmol})$ was added to a solution of imidazolinium halide $(0.5 \mathrm{mmol})$ in THF $(5-8 \mathrm{~mL})$. After stirring the reaction mixture at $\mathrm{rt}$ for $18 \mathrm{~h}$, the reaction mixture was filtered and the filtrate transferred to a Schlenk tube containing $[\mathrm{Rh}(\operatorname{cod}) \mathrm{Cl}]_{2}$ or $[\mathrm{Ir}(\operatorname{cod}) \mathrm{Cl}]_{2}(0.23-0.24 \mathrm{mmol})$. THF $(10 \mathrm{~mL})$ was added, and the reaction mixture was stirred at reflux for $18 \mathrm{~h}$. After cooling, the mixture was filtered through a pad of Celite, concentrated in vacuo, and purified using flash column chromatography (pentane/DCM $=4: 1$, gradient).

General Procedure IV for the Synthesis of $\mathrm{M}(\operatorname{cod}) \mathbf{X}(\mathrm{NHC})$ Complexes. Reactions were carried out at a concentration of 0.04 $\mathrm{M}$ of imdazol(in)ium salt in dry THF. A Schlenk tube was charged with imidazol(in)ium salt ( 1 equiv), $\mathrm{KO}^{t} \mathrm{Bu}$ ( 1 equiv), $[\mathrm{Rh}(\mathrm{cod})-$ $\mathrm{Cl}]_{2}$ or $[\mathrm{Ir}(\mathrm{cod}) \mathrm{Cl}]_{2}(0.95$ equiv), and $\mathrm{KI}$ (3 equiv). THF was added and the reaction mixture was stirred at $\mathrm{rt}$ for $18 \mathrm{~h}$. Then, the mixture was filtered through a pad of Celite, concentrated in vacuo, and purified using flash column chromatography (pentane/DCM $=4: 1$, gradient).

Rh-NHC Complex 35. Method A. According to General Procedure III, reaction between imidazolinium iodide 23 (209 mg, $0.5 \mathrm{mmol}), \mathrm{NaH}(12 \mathrm{mg}, 0.5 \mathrm{mmol}),[\mathrm{Rh}(\operatorname{cod}) \mathrm{Cl}]_{2}(113 \mathrm{mg}, 0.23$ $\mathrm{mmol}$ ), and KI (249 $\mathrm{mg}, 1.5 \mathrm{mmol})$, followed by flash column chromatography, afforded 35 (150 mg, 52\%) as an orange-yellow solid.

Method B. According to General Procedure IV, reaction between imidazolinium iodide 23 (209 mg, $0.5 \mathrm{mmol}$ ), $\mathrm{KO}^{t} \mathrm{Bu}$ (56 mg, 0.5 $\mathrm{mmol}),[\mathrm{Rh}(\operatorname{cod}) \mathrm{Cl}]_{2}(113 \mathrm{mg}, 0.23 \mathrm{mmol})$, and $\mathrm{KI}(249 \mathrm{mg}, 1.5$ $\mathrm{mmol})$, followed by flash column chromatography, afforded 35 (238 $\mathrm{mg}, 82 \%)$ as an orange-yellow solid. ${ }^{1} \mathrm{H}$ NMR $(250 \mathrm{MHz}$, $\left.\mathrm{CDCl}_{3}\right): \delta(\mathrm{ppm}) 7.86-7.83(\mathrm{~m}, 1 \mathrm{H}), 7.71-7.66(\mathrm{~m}, 2 \mathrm{H}), 7.47-$ $7.23(\mathrm{~m}, 5 \mathrm{H}), 5.22(\mathrm{br} \mathrm{s}, 2 \mathrm{H}), 4.08(\mathrm{~d}, J=10.8 \mathrm{~Hz}, 1 \mathrm{H}), 3.96(\mathrm{~d}$, $J=10.8 \mathrm{~Hz}, 1 \mathrm{H}), 3.65($ br s, 2H), $3.19(\mathrm{~s}, 3 \mathrm{H}), 2.37-2.21(\mathrm{~m}$, $3 \mathrm{H}), 2.15-2.07(\mathrm{~m}, 2 \mathrm{H}), 1.90(\mathrm{~s}, 9 \mathrm{H}), 1.82-1.73(\mathrm{~m}, 3 \mathrm{H}) .{ }^{13} \mathrm{C}$ NMR (63 MHz, $\left.\mathrm{CDCl}_{3}\right): \delta(\mathrm{ppm}) 213.3(\mathrm{~d}, J=43.5 \mathrm{~Hz}, \mathrm{C}), 145.7$ (C), $145.1(\mathrm{C}), 140.5(\mathrm{C}), 139.4(\mathrm{C}), 129.5(\mathrm{CH}), 129.4(\mathrm{CH}), 129.0$ $(\mathrm{CH}), 128.3(\mathrm{CH}), 125.0(\mathrm{CH}), 122.8(\mathrm{CH}), 120.3(\mathrm{CH}), 120.0(\mathrm{CH})$, $95.2(\mathrm{~d}, J=6.9 \mathrm{~Hz}, \mathrm{CH}), 93.5(\mathrm{~d}, J=6.7 \mathrm{~Hz}, \mathrm{CH}), 74.2(\mathrm{C}), 74.0$ $(\mathrm{d}, J=15.4 \mathrm{~Hz}, \mathrm{CH}), 70.4(\mathrm{~d}, J=14.0 \mathrm{~Hz}, \mathrm{CH}), 59.7\left(\mathrm{CH}_{2}\right), 56.6$ (C), $35.3\left(\mathrm{CH}_{3}\right), 33.9\left(\mathrm{CH}_{2}\right), 30.9\left(\mathrm{CH}_{2}\right), 30.2\left(3 \times \mathrm{CH}_{3}\right), 30.2\left(\mathrm{CH}_{2}\right)$, $27.9\left(\mathrm{CH}_{2}\right)$. IR (neat): 1475 (s), 1433 (s). HRMS (EI, $\left.70 \mathrm{eV}\right)$ : calcd for $\mathrm{C}_{28} \mathrm{H}_{34} \mathrm{IN}_{2} \mathrm{Rh}\left(\mathrm{M}^{+}\right)$628.0822, found 628.0820. Crystals suitable for X-ray crystal structure determination were obtained by the slow diffusion of pentane into a saturated solution of $\mathbf{7 5}$ in DCM. Mp: $230-233{ }^{\circ} \mathrm{C}$.

Ir-NHC Complex 36. Method A. According to General Procedure III, reaction between imidazolinium iodide $\mathbf{2 3}$ (209 mg, $0.5 \mathrm{mmol}), \mathrm{NaH}(12 \mathrm{mg}, 0.5 \mathrm{mmol}),[\operatorname{Ir}(\operatorname{cod}) \mathrm{Cl}]_{2}(154 \mathrm{mg}, 0.23$ 
mmol), and KI (249 mg, $1.5 \mathrm{mmol})$, followed by flash column chromatography, afforded $36(182 \mathrm{mg}, 55 \%)$ as an orange solid.

Method B. According to General Procedure IV, reaction between imidazolinium iodide 23 (209 mg, $0.5 \mathrm{mmol}$ ), $\mathrm{KO}^{t} \mathrm{Bu}$ (56 mg, 0.5 $\mathrm{mmol}),[\mathrm{Ir}(\operatorname{cod}) \mathrm{Cl}]_{2}(154 \mathrm{mg}, 0.23 \mathrm{mmol})$, and $\mathrm{KI}(249 \mathrm{mg}, 1.5$ $\mathrm{mmol}$ ), followed by flash column chromatography, afforded $\mathbf{3 6}$ (209 $\mathrm{mg}, 63 \%$ ) as an orange solid, which could be recrystallized by the slow diffusion of pentane into a saturated solution of the complex in DCM. Mp: $236-238{ }^{\circ} \mathrm{C}$ (dec). ${ }^{1} \mathrm{H}$ NMR $\left(250 \mathrm{MHz}, \mathrm{CDCl}_{3}\right)$ : $\delta$ (ppm) 7.88-7.85 (m, 1H), 7.72-7.67 (m, 2H), 7.49-7.29 (m, $5 \mathrm{H}), 4.83-4.72(\mathrm{~m}, 2 \mathrm{H}), 4.13(\mathrm{~d}, J=10.9 \mathrm{~Hz}, 1 \mathrm{H}), 4.04(\mathrm{~d}, J=$ $10.9 \mathrm{~Hz}, 1 \mathrm{H}), 3.25-3.13(\mathrm{~m}, 2 \mathrm{H}), 3.02(\mathrm{~s}, 3 \mathrm{H}), 2.34-2.24(\mathrm{~m}$, $1 \mathrm{H}), 2.18-1.84(\mathrm{~m}, 4 \mathrm{H}), 1.81(\mathrm{~s}, 9 \mathrm{H}), 1.56-1.29(\mathrm{~m}, 3 \mathrm{H}),{ }^{13} \mathrm{C}$ NMR (101 MHz, $\left.\mathrm{CDCl}_{3}\right): \delta(\mathrm{ppm}) 209.0$ (C), 145.7 (C), 145.1 (C), $140.5(\mathrm{C}), 139.6(\mathrm{C}), 129.53(\mathrm{CH}), 129.50(\mathrm{CH}), 129.0(\mathrm{CH})$, $128.4(\mathrm{CH}), 124.8(\mathrm{CH}), 122.9(\mathrm{CH}), 120.9(\mathrm{CH}), 120.0(\mathrm{CH}), 80.5$ $(\mathrm{CH}), 79.7(\mathrm{CH}), 74.4(\mathrm{C}), 60.1\left(\mathrm{CH}_{2}\right), 56.94(\mathrm{C}), 56.93(\mathrm{CH}), 54.3$ $(\mathrm{CH}), 35.0\left(\mathrm{CH}_{3}\right), 34.4\left(\mathrm{CH}_{2}\right), 31.5\left(\mathrm{CH}_{2}\right), 30.8\left(\mathrm{CH}_{2}\right), 30.6$ $\left(3 \times \mathrm{CH}_{3}\right), 28.6\left(\mathrm{CH}_{2}\right)$. IR (neat) 1473 (s), 1448 (s), 1429 (s), 1304 (s). HRMS (EI, $70 \mathrm{eV}$ ) calcd for $\mathrm{C}_{28} \mathrm{H}_{34} \operatorname{Ir} \mathrm{Ir}_{2}\left(\mathrm{M}^{+}\right)$718.1396, found 718.1370. Anal. Calcd for $\mathrm{C}_{28} \mathrm{H}_{34} \operatorname{IIrN}_{2}(\%)$ : C 46.86, H 4.77, N 3.90. Found: C 46.62, H 4.78, N 3.87.

Rh-NHC Complex 37. Method A. According to General Procedure III, reaction between imidazolinium iodide $\mathbf{3 0}(201 \mathrm{mg}$, $0.5 \mathrm{mmol}), \mathrm{NaH}(12 \mathrm{mg}, 0.5 \mathrm{mmol}),[\mathrm{Rh}(\mathrm{cod}) \mathrm{Cl}]_{2}(113 \mathrm{mg}, 0.23$ $\mathrm{mmol}$ ), and KI (249 $\mathrm{mg}, 1.5 \mathrm{mmol}$ ), followed by flash column chromatography, afforded $37(143 \mathrm{mg}, 51 \%)$ as a $89: 11$ mixture of rotamers as an orange-yellow solid.

Method B. According to General Procedure IV, reaction between imidazolinium iodide 30 (300 mg, $0.75 \mathrm{mmol}), \mathrm{KO}^{t} \mathrm{Bu}(84 \mathrm{mg}$, $0.75 \mathrm{mmol}),[\mathrm{Rh}(\operatorname{cod}) \mathrm{Cl}]_{2}(176 \mathrm{mg}, 0.35 \mathrm{mmol})$, and $\mathrm{KI}(374 \mathrm{mg}$, $2.25 \mathrm{mmol}$ ), followed by flash column chromatography, afforded $37(271 \mathrm{mg}, 63 \%)$ as a 78:22 mixture of rotamers as a yellow solid. Main isomer: ${ }^{1} \mathrm{H}$ NMR $\left(250 \mathrm{MHz}, \mathrm{CDCl}_{3}\right): \delta(\mathrm{ppm}) 7.47-7.33$ (m, 5H), 5.22-5.19 (m, 2H), $4.41(\mathrm{~d}, J=11.3 \mathrm{~Hz}, 1 \mathrm{H}), 3.92$ (s, $3 \mathrm{H}), 3.78(\mathrm{~d}, J=11.3 \mathrm{~Hz}, 1 \mathrm{H}), 3.72-3.60(\mathrm{~m}, 1 \mathrm{H}), 3.69(\mathrm{~s}, 3 \mathrm{H})$, $3.48-3.41(\mathrm{~m}, 1 \mathrm{H}), 2.55-2.37(\mathrm{~m}, 2 \mathrm{H}), 2.29-2.04(\mathrm{~m}, 3 \mathrm{H}), 1.94-$ $1.88(\mathrm{~m}, 1 \mathrm{H}), 1.82(\mathrm{~s}, 9 \mathrm{H}), 1.77-1.64(\mathrm{~m}, 2 \mathrm{H}) .{ }^{13} \mathrm{C}$ NMR $(63 \mathrm{MHz}$, $\left.\mathrm{CDCl}_{3}\right): \delta(\mathrm{ppm}) 213.3(\mathrm{~d}, J=43.8 \mathrm{~Hz}, \mathrm{C}), 171.7(\mathrm{C}), 137.8(\mathrm{C})$, $129.1(2 \times \mathrm{CH}), 128.6(\mathrm{CH}), 126.7(2 \times \mathrm{CH}), 95.3(\mathrm{~d}, J=7.0 \mathrm{~Hz}$, $\mathrm{CH}), 93.4(\mathrm{~d}, J=6.7 \mathrm{~Hz}, \mathrm{CH}), 74.9(\mathrm{C}), 73.9(\mathrm{~d}, J=15.3 \mathrm{~Hz}$, $\mathrm{CH}), 70.8(\mathrm{~d}, J=14.0 \mathrm{~Hz}, \mathrm{CH}), 60.9\left(\mathrm{CH}_{2}\right), 56.8(\mathrm{C}), 52.8\left(\mathrm{CH}_{3}\right)$, $37.8\left(\mathrm{CH}_{3}\right), 33.9\left(\mathrm{CH}_{2}\right), 30.9\left(\mathrm{CH}_{2}\right), 30.1\left(3 \times \mathrm{CH}_{3}\right), 30.0\left(\mathrm{CH}_{2}\right)$, $27.9\left(\mathrm{CH}_{2}\right)$. IR (neat): 1739 (s), $1475(\mathrm{~m}), 1433$ (s), 1221 (s). HRMS (EI, $70 \mathrm{eV}$ ): calcd for $\mathrm{C}_{24} \mathrm{H}_{34} \mathrm{IN}_{2} \mathrm{O}_{2} \mathrm{Rh}\left(\mathrm{M}^{+}\right)$612.0720, found 612.0739. Anal. Calcd for $\mathrm{C}_{24} \mathrm{H}_{34} \mathrm{IN}_{2} \mathrm{O}_{2} \mathrm{Rh}(\%)$ : C 47.07, $\mathrm{H}$ 5.60, N 4.57. Found: C 46.46, H 5.45, N 4.63.

Ir-NHC Complex 38. Method A. According to General Procedure III, reaction between imidazolinium iodide $\mathbf{3 0}(201 \mathrm{mg}$, $0.5 \mathrm{mmol}), \mathrm{NaH}(12 \mathrm{mg}, 0.5 \mathrm{mmol}),[\mathrm{Ir}(\operatorname{cod}) \mathrm{Cl}]_{2}(154 \mathrm{mg}, 0.23$ $\mathrm{mmol}$ ), and KI (249 $\mathrm{mg}, 1.5 \mathrm{mmol}$ ), followed by flash column chromatography, afforded two rotamers of $\mathbf{3 8}$ (least polar fraction 38a: $88 \mathrm{mg}, 27 \%$; most polar fraction 38b: $81 \mathrm{mg}, 25 \%$ ) as orange solids.

Method B. According to General Procedure IV, reaction between imidazolinium iodide $\mathbf{3 0}$ (201 mg, $0.5 \mathrm{mmol}$ ), $\mathrm{KO}^{t} \mathrm{Bu}$ (56 mg, 0.5 $\mathrm{mmol}),[\mathrm{Ir}(\mathrm{cod}) \mathrm{Cl}]_{2}(154 \mathrm{mg}, 0.23 \mathrm{mmol})$, and KI (249 mg, 1.5 $\mathrm{mmol}$ ), followed by flash column chromatography, afforded two rotamers of $\mathbf{3 8}$ (least polar fraction 38a: $91 \mathrm{mg}, 28 \%$; most polar fraction 38b: $67 \mathrm{mg}, 21 \%$ ) as orange solids.

Method C. According to General Procedure IV, reaction between imidazolinium iodide 30 (201 mg, $0.5 \mathrm{mmol}$ ), $\mathrm{KO}^{t} \mathrm{Bu}$ (56 mg, 0.5 $\mathrm{mmol}),[\mathrm{Ir}(\operatorname{cod}) \mathrm{Cl}]_{2}(154 \mathrm{mg}, 0.23 \mathrm{mmol})$, and KI (249 mg, 1.5 mmol) in refluxing THF, followed by flash column chromatography, afforded two rotamers of $\mathbf{3 8}$ (least polar fraction 38a: $122 \mathrm{mg}$, 38\%; most polar fraction 38b: $60 \mathrm{mg}, 19 \%$ ) as orange solids. 38a: ${ }^{1} \mathrm{H} \mathrm{NMR}\left(250 \mathrm{MHz}, \mathrm{CDCl}_{3}\right): \delta$ (ppm) 7.39-7.27 (m, 5H), 4.70- $4.64(\mathrm{~m}, 2 \mathrm{H}), 4.40(\mathrm{~d}, J=11.3 \mathrm{~Hz}, 1 \mathrm{H}), 3.84(\mathrm{~s}, 3 \mathrm{H}), 3.72(\mathrm{~d}, J$ $=11.3 \mathrm{~Hz}, 1 \mathrm{H}), 3.43(\mathrm{~s}, 3 \mathrm{H}), 3.17-3.14(\mathrm{~m}, 1 \mathrm{H}), 2.90-2.88(\mathrm{~m}$, $1 \mathrm{H}), 2.19-1.82(\mathrm{~m}, 5 \mathrm{H}), 1.64(\mathrm{~s}, 9 \mathrm{H}), 1.56-1.35(\mathrm{~m}, 2 \mathrm{H}), 1.22-$ $1.20(\mathrm{~m}, 1 \mathrm{H}) .{ }^{13} \mathrm{C}$ NMR $\left(63 \mathrm{MHz}, \mathrm{CDCl}_{3}\right): \delta(\mathrm{ppm}) 208.8(\mathrm{C})$, $171.2(\mathrm{C}), 137.7(\mathrm{C}), 129.1(2 \times \mathrm{CH}), 128.7(\mathrm{CH}), 126.7(2 \times \mathrm{CH})$, $80.7(\mathrm{CH}), 79.9(\mathrm{CH}), 74.9(\mathrm{C}), 61.3\left(\mathrm{CH}_{2}\right), 57.1(\mathrm{C}), 56.9(\mathrm{CH})$, $54.7(\mathrm{CH}), 52.9\left(\mathrm{CH}_{3}\right), 37.6\left(\mathrm{CH}_{3}\right), 34.4\left(\mathrm{CH}_{2}\right), 31.5\left(\mathrm{CH}_{2}\right), 30.6$ $\left(\mathrm{CH}_{2}\right), 30.5\left(3 \times \mathrm{CH}_{3}\right), 28.5\left(\mathrm{CH}_{2}\right)$. IR (neat) $1738(\mathrm{~s}), 1238(\mathrm{~m})$. HRMS (EI, $70 \mathrm{eV}$ ) calcd for $\mathrm{C}_{24} \mathrm{H}_{34} \mathrm{IIrN}_{2} \mathrm{O}_{2}\left(\mathrm{M}^{+}\right) 702.1294$, found 702.1289. Crystals suitable for X-ray crystal structure determination were obtained by the slow diffusion of pentane into a saturated solution of 38a in dichloromethane (DCM). Mp 177-179 ${ }^{\circ} \mathrm{C}$. 38b: ${ }^{1} \mathrm{H}$ NMR $\left(250 \mathrm{MHz}, \mathrm{CDCl}_{3}\right)$ : $\delta$ (ppm) 7.38-7.30 (m, 3H), $7.16-7.13(\mathrm{~m}, 2 \mathrm{H}), 4.70$ (br s, 2H), $4.54(\mathrm{~d}, J=11.1 \mathrm{~Hz}, 1 \mathrm{H})$, $3.86(\mathrm{~s}, 3 \mathrm{H}), 3.54(\mathrm{~d}, J=11.1 \mathrm{~Hz}, 1 \mathrm{H}), 3.42(\mathrm{~s}, 3 \mathrm{H}), 3.12-3.10$ $(\mathrm{m}, 1 \mathrm{H}), 3.03-3.00(\mathrm{~m}, 1 \mathrm{H}), 2.18-1.80(\mathrm{~m}, 5 \mathrm{H}), 1.63(\mathrm{~s}, 9 \mathrm{H})$, $1.39-1.20(\mathrm{~m}, 3 \mathrm{H}) ;{ }^{13} \mathrm{C}$ NMR $\left(101 \mathrm{MHz}, \mathrm{CDCl}_{3}\right): \delta(\mathrm{ppm}) 209.2$ (C), $170.6(\mathrm{C}), 137.4(\mathrm{C}), 129.0(2 \times \mathrm{CH}), 128.6(\mathrm{CH}), 126.2$ $(2 \times \mathrm{CH}), 80.9(\mathrm{CH}), 79.7(\mathrm{CH}), 75.6(\mathrm{C}), 60.9\left(\mathrm{CH}_{2}\right), 56.9(\mathrm{C})$, $56.0(\mathrm{CH}), 54.5(\mathrm{CH}), 52.9\left(\mathrm{CH}_{3}\right), 37.8\left(\mathrm{CH}_{3}\right), 34.1\left(\mathrm{CH}_{2}\right), 31.11$ $\left(\mathrm{CH}_{2}\right), 31.06\left(\mathrm{CH}_{2}\right), 30.6\left(3 \times \mathrm{CH}_{3}\right), 28.9\left(\mathrm{CH}_{2}\right)$; IR (neat) 1736 (s), 1217 (m); HRMS (EI, $70 \mathrm{eV}$ ) calcd for $\mathrm{C}_{24} \mathrm{H}_{34} \mathrm{IIrN}_{2} \mathrm{O}_{2}\left(\mathrm{M}^{+}\right)$ 702.1294, found 702.1276. Crystals suitable for X-ray crystal structure determination were obtained by the slow diffusion of pentane into a saturated solution of $\mathbf{3 8 b}$ in DCM. Mp 178$180^{\circ} \mathrm{C}$.

2-Imidazolinium Hexafluorophosphate 39. $\mathrm{AgPF}_{6}(384 \mathrm{mg}$, $1.52 \mathrm{mmol}$ ) was added to a solution of imidazolinium iodide $\mathbf{3 0}$ (612 $\mathrm{mg}, 1.52 \mathrm{mmol})$ in DCM (12 mL). While stirring the reaction mixture at $\mathrm{rt}$, a yellow precipitate was formed. After $15 \mathrm{~min}$, the suspension was filtered and the filtrate concentrated in vacuo and washed with pentane to afford salt 39 as a white solid $(611 \mathrm{mg}$, 96\%). ${ }^{1} \mathrm{H}$ NMR $\left(250 \mathrm{MHz}, \mathrm{CDCl}_{3}\right): \delta(\mathrm{ppm}) 8.75$ (s, 1H), 7.51$7.46(\mathrm{~m}, 3 \mathrm{H}), 7.29-7.27(\mathrm{~m}, 2 \mathrm{H}), 4.83(\mathrm{~d}, J=12.2 \mathrm{~Hz}, 1 \mathrm{H}), 4.02$ $(\mathrm{s}, 3 \mathrm{H}), 3.96(\mathrm{~d}, J=12.2 \mathrm{~Hz}, 1 \mathrm{H}), 3.29(\mathrm{~s}, 3 \mathrm{H}), 1.50(\mathrm{~s}, 9 \mathrm{H}) \cdot{ }^{13} \mathrm{C}$ NMR (101 MHz, $\left.\mathrm{CDCl}_{3}\right)$ : $\delta(\mathrm{ppm}) 168.9(\mathrm{C}), 156.9(\mathrm{CH})$, $134.0(\mathrm{C}), 130.1(\mathrm{CH}), 129.9(2 \times \mathrm{CH}), 126.1(2 \times \mathrm{CH}), 75.9(\mathrm{C})$, $57.83(\mathrm{C}), 57.79\left(\mathrm{CH}_{2}\right), 54.0(\mathrm{CH} 3), 33.1\left(\mathrm{CH}_{3}\right), 27.5\left(3 \times \mathrm{CH}_{3}\right)$. IR (neat) 1747 (s), 1641 (s), 1267 (m), 839 (s). HRMS (EI, 70 $\mathrm{eV}$ ): calcd for $\mathrm{C}_{16} \mathrm{H}_{23} \mathrm{~N}_{2} \mathrm{O}_{2}{ }^{+}$(cation) 275.1754, found 275.1745 .

Rh-NHC Complex 40. A Schlenk tube was charged with imidazolinium salt $39(210 \mathrm{mg}, 0.5 \mathrm{mmol}), \mathrm{KO}^{t} \mathrm{Bu}(56 \mathrm{mg}, 0.5$ $\mathrm{mmol}),[\mathrm{Rh}(\mathrm{cod}) \mathrm{Cl}]_{2}(106 \mathrm{mg}, 0.215 \mathrm{mmol})$, and tetraethylammonium chloride $(248 \mathrm{mg}, 1.5 \mathrm{mmol})$. THF $(10 \mathrm{~mL})$ was added, and the reaction mixture was stirred at $\mathrm{rt}$ for $18 \mathrm{~h}$. Then, the mixture was filtered through a pad of Celite, concentrated in vacuo, and purified using flash column chromatography (pentane/DCM $=1: 2$, DCM, DCM/EtOAc $=8: 1)$ to afford $\mathbf{4 0}(175 \mathrm{mg}, 79 \%)$ as a 78:22 mixture of rotamers as a yellow-orange solid. Main isomer: ${ }^{1} \mathrm{H}$ NMR (250 MHz, $\left.\mathrm{CDCl}_{3}\right): \delta(\mathrm{ppm}) 7.36-7.19(\mathrm{~m}, 5 \mathrm{H}), 4.89(\mathrm{br}$ $\mathrm{s}, 2 \mathrm{H}), 4.29(\mathrm{~d}, J=11.3 \mathrm{~Hz}, 1 \mathrm{H}), 3.82(\mathrm{~s}, 3 \mathrm{H}), 3.74(\mathrm{~s}, 3 \mathrm{H}), 3.63$ $(\mathrm{d}, J=11.3 \mathrm{~Hz}, 1 \mathrm{H}), 3.49-3.38(\mathrm{~m}, 1 \mathrm{H}), 3.23-3.17(\mathrm{~m}, 1 \mathrm{H})$, $2.47-2.13(\mathrm{~m}, 4 \mathrm{H}), 1.94-1.83(\mathrm{~m}, 2 \mathrm{H}), 1.74(\mathrm{~s}, 9 \mathrm{H}), 1.73-1.63$ (m, 2H). ${ }^{13} \mathrm{C}$ NMR $\left(63 \mathrm{MHz}, \mathrm{CDCl}_{3}\right): \delta(\mathrm{ppm}) 213.8(\mathrm{~d}, J=45.9$ $\mathrm{Hz}, \mathrm{C}), 171.5(\mathrm{C}), 137.7(\mathrm{C}), 129.1(2 \times \mathrm{CH}), 128.6(\mathrm{CH}), 126.3$ $(2 \times \mathrm{CH}), 97.4(\mathrm{~d}, J=7.0 \mathrm{~Hz}, \mathrm{CH}), 95.1(\mathrm{~d}, J=6.2 \mathrm{~Hz}, \mathrm{CH}), 75.0$ (C), $70.9(\mathrm{~d}, J=15.5 \mathrm{~Hz}, \mathrm{CH}), 67.3(\mathrm{~d}, J=14.5 \mathrm{~Hz}, \mathrm{CH}), 60.6$ $\left(\mathrm{CH}_{2}\right), 56.8(\mathrm{C}), 52.8\left(\mathrm{CH}_{3}\right), 37.3\left(\mathrm{CH}_{3}\right), 33.5\left(\mathrm{CH}_{2}\right), 31.3\left(\mathrm{CH}_{2}\right)$, $30.3\left(3 \times \mathrm{CH}_{3}\right), 29.4\left(\mathrm{CH}_{2}\right), 27.9\left(\mathrm{CH}_{2}\right)$. IR (neat): 1739 (s), 1475 (m), $1435(\mathrm{~m}), 1223(\mathrm{~m})$. HRMS (EI, $70 \mathrm{eV})$ : calcd for $\mathrm{C}_{24} \mathrm{H}_{34}{ }^{-}$ $\mathrm{ClN}_{2} \mathrm{O}_{2} \mathrm{Rh}\left(\mathrm{M}^{+}\right)$520.1364, found 520.1375.

2-Imidazolinium Tosylate 41. According to General Procedure II, alkylation of imidazoline 22 (203 $\mathrm{mg}, 0.74 \mathrm{mmol}$ ) with methyl tosylate (141 mg, $0.74 \mathrm{mmol})$, followed by washing with pentane, afforded salt 41 (336 mg, 99\%) as a white solid. ${ }^{1} \mathrm{H}$ NMR (250 $\left.\mathrm{MHz}, \mathrm{CDCl}_{3}\right): \delta(\mathrm{ppm}) 9.70(\mathrm{~s}, 1 \mathrm{H}), 7.75(\mathrm{~d}, J=8.1 \mathrm{~Hz}, 2 \mathrm{H})$, $7.64(\mathrm{~d}, J=7.4 \mathrm{~Hz}, 2 \mathrm{H}), 7.54-7.33(\mathrm{~m}, 6 \mathrm{H}), 7.06(\mathrm{~d}, J=8.0 \mathrm{~Hz}$, 
2H), 4.17 (s, 2H), 2.75 (s, 3H), 2.26 (s, 3H), 1.54 (s, 9H). ${ }^{13} \mathrm{C} \mathrm{NMR}$ $\left(63 \mathrm{MHz}, \mathrm{CDCl}_{3}\right): \delta(\mathrm{ppm}) 158.8(\mathrm{CH}), 143.9(\mathrm{C}), 141.9(2 \times \mathrm{C})$, $140.2(2 \times \mathrm{C}), 138.9(\mathrm{C}), 131.0(2 \times \mathrm{CH}), 129.4(2 \times \mathrm{CH}), 128.5$ $(2 \times \mathrm{CH}), 126.0(2 \times \mathrm{CH}), 124.1(2 \times \mathrm{CH}), 120.7(2 \times \mathrm{CH}), 74.8(\mathrm{C})$, $57.6(\mathrm{C}), 56.7\left(\mathrm{CH}_{2}\right), 30.5\left(\mathrm{CH}_{3}\right), 28.0\left(3 \times \mathrm{CH}_{3}\right), 21.2\left(\mathrm{CH}_{3}\right)$. IR (neat): 1475 (s), 1433 (s). HRMS (EI, $70 \mathrm{eV}$ ): calcd for $\mathrm{C}_{20} \mathrm{H}_{23} \mathrm{~N}_{2}{ }^{+}$ (cation) 291.1856, found 291.1849.

Rh-NHC Complex 42. A Schlenk tube was charged with imidazolinium salt 41 (231 mg, $0.5 \mathrm{mmol}), \mathrm{KO}^{t} \mathrm{Bu}(56 \mathrm{mg}, 0.5$ $\mathrm{mmol}),[\mathrm{Rh}(\mathrm{cod}) \mathrm{Cl}]_{2}(123 \mathrm{mg}, 0.25 \mathrm{mmol})$, and $\mathrm{LiCl}$ (64 mg, 1.5 mmol). THF $(10 \mathrm{~mL})$ was added and the reaction mixture was stirred at $\mathrm{rt}$ for $18 \mathrm{~h}$. Then, the mixture was filtered through a pad of Celite and concentrated in vacuo. The residue was taken into DCM, washed with water, dried with $\mathrm{Na}_{2} \mathrm{SO}_{4}$, concentrated in vacuo, and purified using flash column chromatography (DCM, $\mathrm{DCM} / \mathrm{EtOAc}=20: 1$, gradient $)$ to afford $40(75 \mathrm{mg}, 27 \%)$ as a yellow-orange solid. ${ }^{1} \mathrm{H} \mathrm{NMR}\left(400 \mathrm{MHz}, \mathrm{CDCl}_{3}\right): \delta(\mathrm{ppm}) 7.68-$ $7.63(\mathrm{~m}, 3 \mathrm{H}), 7.42-7.29(\mathrm{~m}, 4 \mathrm{H}), 7.20$ (d, $J=7.4 \mathrm{~Hz}, 1 \mathrm{H}), 4.99-$ $4.94(\mathrm{~m}, 2 \mathrm{H}), 4.01(\mathrm{~d}, J=10.8 \mathrm{~Hz}, 1 \mathrm{H}), 3.89(\mathrm{~d}, J=10.8 \mathrm{~Hz}$, $1 \mathrm{H}), 3.44-3.40(\mathrm{~m}, 2 \mathrm{H}), 3.28(\mathrm{~s}, 3 \mathrm{H}), 2.45-2.33(\mathrm{~m}, 3 \mathrm{H}), 2.23-$ $2.20(\mathrm{~m}, 1 \mathrm{H}), 1.97-1.91(\mathrm{~m}, 2 \mathrm{H}), 1.88(\mathrm{~s}, 9 \mathrm{H}), 1.86-1.75(\mathrm{~m}$, 2H). ${ }^{13} \mathrm{C} \mathrm{NMR}\left(63 \mathrm{MHz}, \mathrm{CDCl}_{3}\right): \delta(\mathrm{ppm}) 214.0(\mathrm{~d}, J=45.6 \mathrm{~Hz}$, C), 145.5 (C), 145.0 (C), 140.5 (C), 139.4 (C), $129.47(\mathrm{CH}), 129.45$ $(\mathrm{CH}), 129.0(\mathrm{CH}), 128.3(\mathrm{CH}), 124.6(\mathrm{CH}), 122.8(\mathrm{CH}), 120.3(\mathrm{CH})$, $120.0(\mathrm{CH}), 97.4(\mathrm{~d}, J=7.2 \mathrm{~Hz}, \mathrm{CH}), 94.9(\mathrm{~d}, J=7.0 \mathrm{~Hz}, \mathrm{CH})$, $74.4(\mathrm{C}), 70.7$ (d, $J=15.7 \mathrm{~Hz}, \mathrm{CH}), 67.0$ (d, $J=14.5 \mathrm{~Hz}, \mathrm{CH})$, $59.6\left(\mathrm{CH}_{2}\right), 56.7(\mathrm{C}), 34.6\left(\mathrm{CH}_{3}\right), 33.5\left(\mathrm{CH}_{2}\right), 31.5\left(\mathrm{CH}_{2}\right), 30.4$ $\left(3 \times \mathrm{CH}_{3}\right), 29.4\left(\mathrm{CH}_{2}\right), 28.0\left(\mathrm{CH}_{2}\right)$. IR (neat): $1473(\mathrm{~s}), 1450(\mathrm{~s})$, 1435 (s). HRMS (EI, $70 \mathrm{eV}$ ): calcd for $\mathrm{C}_{28} \mathrm{H}_{34} \mathrm{ClN}_{2} \mathrm{Rh}\left(\mathrm{M}^{+}\right)$ 536.1466, found 536.1473.

Rh-NHC Complex 43. A Schlenk tube was charged with imidazolinium chloride $24(222 \mathrm{mg}, 0.5 \mathrm{mmol}), \mathrm{KO}^{t} \mathrm{Bu}(56 \mathrm{mg}$, $0.5 \mathrm{mmol})$, and $[\mathrm{Rh}(\mathrm{cod}) \mathrm{Cl}]_{2}(118 \mathrm{mg}, 0.24 \mathrm{mmol})$. THF $(10 \mathrm{~mL})$ was added, and the reaction mixture was stirred at $\mathrm{rt}$ for $18 \mathrm{~h}$. Then, the mixture was filtered through a pad of Celite, concentrated in vacuo, and purified using flash column chromatography (DCM, $\mathrm{DCM} / \mathrm{EtOAc}=3: 1)$ to afford $\mathbf{4 3}(170 \mathrm{mg}, 54 \%)$ as a yellow-orange solid. ${ }^{1} \mathrm{H}$ NMR $\left(250 \mathrm{MHz}, \mathrm{CDCl}_{3}\right): \delta(\mathrm{ppm}) 7.55(\mathrm{~d}, J=7.8 \mathrm{~Hz}$, $1 \mathrm{H}), 7.41(\mathrm{~d}, J=7.4 \mathrm{~Hz}, 1 \mathrm{H}), 7.35-7.17(\mathrm{~m}, 5 \mathrm{H}), 7.10-7.02(\mathrm{~m}$, $1 \mathrm{H}), 6.32$ (br s, 1H), 6.19 (d, $J=14.3 \mathrm{~Hz}, 1 \mathrm{H}), 6.09$ (br s, 1H), $5.31(\mathrm{~d}, J=14.2 \mathrm{~Hz}, 1 \mathrm{H}), 5.12-5.02(\mathrm{~m}, 2 \mathrm{H}), 3.91(\mathrm{~d}, J=10.7$ $\mathrm{Hz}, 1 \mathrm{H}), 3.78-3.73(\mathrm{~m}, 2 \mathrm{H}), 3.77$ (d, $J=10.7 \mathrm{~Hz}, 1 \mathrm{H}), 2.54-$ 2.19 (m, 5H), 1.98 (s, 6H), 1.96 (s, 9H), 1.96 (br s, 3H), 1.70$1.64(\mathrm{~m}, 3 \mathrm{H}) .{ }^{13} \mathrm{C}$ NMR $\left(101 \mathrm{MHz}, \mathrm{CDCl}_{3}\right): \delta(\mathrm{ppm}) 217.8(\mathrm{~d}, J$ $=46.2 \mathrm{~Hz}, \mathrm{C}), 145.1$ (C), $144.5(\mathrm{C}), 140.2$ (C), 139.7 (C), 139.0 (C), $137.1(\mathrm{C}), 136.7(\mathrm{C}), 128.7(\mathrm{CH}), 128.4(\mathrm{CH}), 128.1(\mathrm{C}), 128.0$ $(\mathrm{CH}), 127.5(\mathrm{CH}), 124.5(\mathrm{CH}), 123.7(\mathrm{CH}), 122.4(\mathrm{CH}), 119.9(\mathrm{CH})$, $119.6(\mathrm{CH}), 119.3(\mathrm{CH}), 97.2(\mathrm{~d}, J=7.4 \mathrm{~Hz}, \mathrm{CH}), 94.7(\mathrm{~d}, J=$ $6.9 \mathrm{~Hz}, \mathrm{CH}), 73.8(\mathrm{C}), 69.2(\mathrm{~d}, J=14.7 \mathrm{~Hz}, \mathrm{CH}), 68.8(\mathrm{~d}, J=$ $15.2 \mathrm{~Hz}, \mathrm{CH}), 61.2\left(\mathrm{CH}_{2}\right), 57.3(\mathrm{C}), 50.4\left(\mathrm{CH}_{2}\right), 32.6\left(\mathrm{CH}_{2}\right), 32.3$ $\left(\mathrm{CH}_{2}\right), 30.5\left(3 \times \mathrm{CH}_{3}\right), 28.7\left(\mathrm{CH}_{2}\right), 28.4\left(\mathrm{CH}_{2}\right), 27.4\left(\mathrm{CH}_{3}\right), 20.4$ $\left(\mathrm{CH}_{3}\right), p-\mathrm{CH}_{3}$ of mesityl group could not be observed. IR (neat): 1691 (m), 1450 (s), 1200 (s). HRMS (EI, $70 \mathrm{eV}$ ): calcd for $\mathrm{C}_{37} \mathrm{H}_{44}{ }^{-}$ $\mathrm{ClN}_{2} \mathrm{Rh}\left(\mathrm{M}^{+}\right)$654.2248, found 654.2250.

Rh-NHC Complex 44. According to General Procedure IV, reaction between imidazolinium bromide $26(553 \mathrm{mg}, 0.5 \mathrm{mmol})$, $\mathrm{KO}^{t} \mathrm{Bu}(56 \mathrm{mg}, 0.5 \mathrm{mmol}),[\mathrm{Rh}(\operatorname{cod}) \mathrm{Cl}]_{2}(118 \mathrm{mg}, 0.24 \mathrm{mmol})$, and KI (249 mg, $1.5 \mathrm{mmol})$, followed by flash column chromatography, afforded $\mathbf{4 4}(314 \mathrm{mg}, 81 \%)$ as a 80:20 mixture of rotamers as a yellow solid. Main isomer: ${ }^{1} \mathrm{H}$ NMR $\left(250 \mathrm{MHz}, \mathrm{CDCl}_{3}\right): \delta$ (ppm) $7.78(\mathrm{~d}, J=8.6 \mathrm{~Hz}, 2 \mathrm{H}), 7.54(\mathrm{~d}, J=7.5 \mathrm{~Hz}, 1 \mathrm{H}), 7.49-$ $6.65(\mathrm{~m}, 14 \mathrm{H}), 5.70(\mathrm{~d}, J=14.1 \mathrm{~Hz}, 1 \mathrm{H}), 5.37-5.22(\mathrm{~m}, 2 \mathrm{H})$, $4.74(\mathrm{~d}, J=14.7 \mathrm{~Hz}, 1 \mathrm{H}), 4.46(\mathrm{~d}, J=14.2 \mathrm{~Hz}, 1 \mathrm{H}), 4.04-3.93$ $(\mathrm{m}, 1 \mathrm{H}), 3.92(\mathrm{~d}, J=4.1 \mathrm{~Hz}, 1 \mathrm{H}), 3.86-3.78(\mathrm{~m}, 2 \mathrm{H}), 3.84(\mathrm{~s}$, $3 \mathrm{H}), 2.52-2.17(\mathrm{~m}, 4 \mathrm{H}), 2.08-1.69(\mathrm{~m}, 5 \mathrm{H}), 0.64(\mathrm{~d}, J=7.2 \mathrm{~Hz}$, $3 \mathrm{H}), 0.48(\mathrm{~d}, J=7.0 \mathrm{~Hz}, 3 \mathrm{H}) .{ }^{13} \mathrm{C} \mathrm{NMR}\left(63 \mathrm{MHz}, \mathrm{CDCl}_{3}\right): \delta$ (ppm) 217.8 (d, $J=45.6 \mathrm{~Hz}, \mathrm{C}), 159.2$ (C), 147.2 (C), 142.0 (C),
$140.7(\mathrm{C}), 138.6(\mathrm{C}), 135.7(2 \times \mathrm{C}), 130.5(2 \times \mathrm{CH}), 129.8(2 \times \mathrm{CH})$, $129.5(\mathrm{CH}), 128.5(\mathrm{CH}), 127.9(\mathrm{CH}), 127.2(2 \times \mathrm{CH}), 127.1(\mathrm{CH})$, $126.9(\mathrm{CH}), 126.5(\mathrm{CH}), 125.4(\mathrm{CH}), 120.2(\mathrm{CH}), 119.1(\mathrm{CH}), 113.8$ $(2 \times \mathrm{CH}), 97.5(\mathrm{~d}, J=6.4 \mathrm{~Hz}, 2 \times \mathrm{CH}), 79.3(\mathrm{C}), 73.6(\mathrm{CH}), 73.1$ $(\mathrm{d}, J=14.2 \mathrm{~Hz}, \mathrm{CH}), 71.9(\mathrm{~d}, J=14.1 \mathrm{~Hz}, \mathrm{CH}), 55.3\left(\mathrm{CH}_{3}\right), 53.5$ $\left(\mathrm{CH}_{2}\right), 52.8\left(\mathrm{CH}_{2}\right), 32.5\left(\mathrm{CH}_{2}\right), 32.1\left(\mathrm{CH}_{2}\right), 29.39\left(\mathrm{CH}_{2}\right), 29.36$ $\left(\mathrm{CH}_{2}\right), 28.7(\mathrm{CH}), 19.9\left(\mathrm{CH}_{3}\right), 18.0\left(\mathrm{CH}_{3}\right) . \mathrm{IR}$ (neat): $1512(\mathrm{~s})$, 1450 (s), 1248 (s). HRMS (EI, $70 \mathrm{eV}$ ): calcd for $\mathrm{C}_{33} \mathrm{H}_{32} \mathrm{~N}_{2} \mathrm{ORh}$ $\left(\mathrm{M}-(\mathrm{I}+\mathrm{cod})^{+}\right) 575.1570$, found 575.1564 (the molecular ion is hardly detectable in the mass spectrometer). Crystals suitable for $\mathrm{X}$-ray crystal structure determination were obtained by the slow diffusion of pentane into a saturated solution of $\mathbf{4 4}$ in DCM. Mp: $186-187^{\circ} \mathrm{C}$.

Rh-NHC Complex 45. According to General Procedure IV, reaction between imidazolinium iodide $28(166 \mathrm{mg}, 0.25 \mathrm{mmol})$, $\mathrm{KO}^{t} \mathrm{Bu}(28 \mathrm{mg}, 0.25 \mathrm{mmol}),[\mathrm{Rh}(\mathrm{cod}) \mathrm{Cl}]_{2}(59 \mathrm{mg}, 0.12 \mathrm{mmol})$, and KI (125 mg, $0.75 \mathrm{mmol})$, followed by flash column chromatography, afforded $\mathbf{4 5}(173 \mathrm{mg}, 82 \%)$ as a 58:42 mixture of rotamers as an orange-yellow solid. ${ }^{1} \mathrm{H}$ NMR $\left(400 \mathrm{MHz}, \mathrm{CDCl}_{3}\right): \delta(\mathrm{ppm})$ 7.87-7.85 $\left(\mathrm{m}, 1 \mathrm{H}^{\mathrm{B}}\right), 7.67-7.62\left(\mathrm{~m}, 1 \mathrm{H}^{\mathrm{A}}+2 \mathrm{H}^{\mathrm{B}}\right), 7.55-7.34(\mathrm{~m}$, $\left.7 \mathrm{H}^{\mathrm{A}}+4 \mathrm{H}^{\mathrm{B}}\right), 7.26-7.21\left(\mathrm{~m}, 1 \mathrm{H}^{\mathrm{B}}\right), 7.11-7.06\left(\mathrm{~m}, 1 \mathrm{H}^{\mathrm{B}}\right), 6.99-6.92$ $\left(\mathrm{m}, 3 \mathrm{H}^{\mathrm{A}}+1 \mathrm{H}^{\mathrm{B}}\right), 6.91-6.88\left(\mathrm{~m}, 1 \mathrm{H}^{\mathrm{A}}+1 \mathrm{H}^{\mathrm{B}}\right), 6.81(\mathrm{~d}, J=7.6 \mathrm{~Hz}$, $\left.1 \mathrm{H}^{\mathrm{B}}\right), 6.54\left(\mathrm{~d}, J=16.9 \mathrm{~Hz}, 1 \mathrm{H}^{\mathrm{A}}\right), 5.90\left(\mathrm{~d}, J=15.3 \mathrm{~Hz}, 1 \mathrm{H}^{\mathrm{B}}\right)$, $5.81\left(\mathrm{~d}, J=17.0 \mathrm{~Hz}, 1 \mathrm{H}^{\mathrm{A}}\right), 5.32\left(\mathrm{~s}, 1 \mathrm{H}^{\mathrm{A}}\right), 5.31-5.26\left(\mathrm{~m}, 1 \mathrm{H}^{\mathrm{B}}\right)$, $5.27\left(\mathrm{~d}, J=15.2 \mathrm{~Hz}, 1 \mathrm{H}^{\mathrm{B}}\right), 5.23-5.13\left(\mathrm{~m}, 2 \mathrm{H}^{\mathrm{A}}+1 \mathrm{H}^{\mathrm{B}}\right), 5.09(\mathrm{~s}$, $\left.1 \mathrm{H}^{\mathrm{B}}\right), 4.74\left(\right.$ br s, $\left.1 \mathrm{H}^{\mathrm{A}}\right), 4.14\left(\right.$ br s, $\left.1 \mathrm{H}^{\mathrm{A}}\right), 3.94\left(\right.$ br s, $\left.1 \mathrm{H}^{\mathrm{B}}\right), 3.83(\mathrm{~s}$, $\left.3 \mathrm{H}^{\mathrm{A}}\right), 3.81\left(\mathrm{~s}, 3 \mathrm{H}^{\mathrm{B}}\right), 3.76\left(\mathrm{~s}, 5 \mathrm{H}^{\mathrm{A}}\right), 3.77-3.75\left(\mathrm{~m}, 1 \mathrm{H}^{\mathrm{B}}\right), 3.75-$ $3.72\left(\mathrm{~m}, 1 \mathrm{H}^{\mathrm{A}}\right), 3.68-3.59\left(\mathrm{~m}, 2 \mathrm{H}^{\mathrm{A}}+1 \mathrm{H}^{\mathrm{B}}\right), 3.60\left(\mathrm{~s}, 5 \mathrm{H}^{\mathrm{B}}\right), 3.58-$ $3.50\left(\mathrm{~m}, 2 \mathrm{H}^{\mathrm{B}}\right), 3.03\left(\right.$ br s, $\left.1 \mathrm{H}^{\mathrm{A}}\right), 3.01\left(\right.$ br s, $\left.1 \mathrm{H}^{\mathrm{B}}\right), 2.94\left(\mathrm{~s}, 3 \mathrm{H}^{\mathrm{A}}\right)$, $2.93\left(\mathrm{~s}, 3 \mathrm{H}^{\mathrm{B}}\right), 2.37-2.22\left(\mathrm{~m}, 2 \mathrm{H}^{\mathrm{A}}+1 \mathrm{H}^{\mathrm{B}}\right), 2.21-2.12\left(\mathrm{~m}, 3 \mathrm{H}^{\mathrm{B}}\right)$, $2.06-1.92\left(\mathrm{~m}, 1 \mathrm{H}^{\mathrm{A}}+1 \mathrm{H}^{\mathrm{B}}\right), 1.87-1.74\left(\mathrm{~m}, 4 \mathrm{H}^{\mathrm{A}}+2 \mathrm{H}^{\mathrm{B}}\right), 1.56-1.47$ $\left(\mathrm{m}, 1 \mathrm{H}^{\mathrm{B}}\right) .{ }^{13} \mathrm{C}$ NMR $\left(101 \mathrm{MHz}, \mathrm{CDCl}_{3}\right): \delta(\mathrm{ppm}) 216.6(\mathrm{~d}, J=$ $\left.45.0 \mathrm{~Hz}, \mathrm{C}^{\mathrm{B}}\right), 216.4\left(\mathrm{~d}, J=44.7 \mathrm{~Hz}, \mathrm{C}^{\mathrm{A}}\right), 158.8\left(\mathrm{C}^{\mathrm{B}}\right), 158.5\left(\mathrm{C}^{\mathrm{A}}\right)$, $147.0\left(\mathrm{C}^{\mathrm{A}}\right), 145.2\left(\mathrm{C}^{\mathrm{B}}\right), 141.9\left(\mathrm{C}^{\mathrm{B}}\right), 141.0\left(\mathrm{C}^{\mathrm{B}}\right), 140.9\left(\mathrm{C}^{\mathrm{A}}\right), 140.7$ $\left(\mathrm{C}^{\mathrm{B}}\right), 140.3\left(\mathrm{C}^{\mathrm{A}}\right), 139.9\left(\mathrm{C}^{\mathrm{A}}\right), 131.8\left(\mathrm{C}^{\mathrm{A}}+\mathrm{C}^{\mathrm{B}}\right), 129.8\left(\mathrm{CH}^{\mathrm{B}}\right), 129.6$ $\left(\mathrm{CH}^{\mathrm{A}}\right), 129.5\left(\mathrm{CH}^{\mathrm{B}}\right), 129.2\left(2 \times \mathrm{CH}^{\mathrm{B}}\right), 129.0\left(\mathrm{CH}^{\mathrm{A}}\right), 128.70\left(\mathrm{CH}^{\mathrm{B}}\right)$, $128.66\left(\mathrm{CH}^{\mathrm{A}}\right), 128.2\left(\mathrm{CH}^{\mathrm{A}}\right), 127.2\left(\mathrm{CH}^{\mathrm{A}}\right), 127.0\left(\mathrm{CH}^{\mathrm{B}}\right), 126.9$ $\left(2 \times \mathrm{CH}^{\mathrm{A}}\right), 125.9\left(\mathrm{CH}^{\mathrm{B}}\right), 124.9\left(\mathrm{CH}^{\mathrm{B}}\right), 122.2\left(\mathrm{CH}^{\mathrm{A}}\right), 120.3\left(\mathrm{CH}^{\mathrm{A}}\right)$, $120.1\left(\mathrm{CH}^{\mathrm{B}}\right), 119.9\left(\mathrm{CH}^{\mathrm{B}}\right), 119.3\left(\mathrm{CH}^{\mathrm{A}}\right), 114.3\left(2 \times \mathrm{CH}^{\mathrm{A}}\right), 113.6$ $\left(2 \times \mathrm{CH}^{\mathrm{B}}\right), 97.4\left(\mathrm{~d}, J=6.2 \mathrm{~Hz}, \mathrm{CH}^{\mathrm{B}}\right), 97.3\left(\mathrm{~d}, J=6.6 \mathrm{~Hz}, \mathrm{CH}^{\mathrm{B}}\right)$, $97.2\left(\mathrm{~d}, J=6.5 \mathrm{~Hz}, \mathrm{CH}^{\mathrm{A}}\right), 96.8\left(\mathrm{~d}, J=6.5 \mathrm{~Hz}, \mathrm{CH}^{\mathrm{A}}\right), 84.4\left(\mathrm{C}^{\mathrm{A}}\right)$, $82.2\left(\mathrm{C}^{\mathrm{A}}\right), 81.4\left(\mathrm{C}^{\mathrm{B}}\right), 80.4\left(\mathrm{C}^{\mathrm{B}}\right), 72.7\left(\mathrm{~d}, J=14.2 \mathrm{~Hz}, \mathrm{CH}^{\mathrm{A}}\right), 72.3$ $\left(\mathrm{d}, J=14.4 \mathrm{~Hz}, \mathrm{CH}^{\mathrm{B}}\right), 71.9\left(\mathrm{~d}, J=13.9 \mathrm{~Hz}, \mathrm{CH}^{\mathrm{A}}\right), 71.7(\mathrm{~d}, J=$ 14.2 Hz, $\left.\mathrm{CH}^{\mathrm{B}}\right), 70.7\left(\mathrm{CH}^{\mathrm{A}}\right), 70.2\left(\mathrm{CH}^{\mathrm{B}}\right), 68.78\left(\mathrm{CH}^{\mathrm{B}}\right), 68.75\left(\mathrm{CH}^{\mathrm{A}}\right)$, $68.6\left(5 \times \mathrm{CH}^{\mathrm{B}}\right), 68.5\left(5 \times \mathrm{CH}^{\mathrm{A}}\right), 68.4\left(\mathrm{CH}^{\mathrm{B}}\right), 67.9\left(\mathrm{CH}^{\mathrm{A}}\right), 67.6\left(\mathrm{CH}^{\mathrm{A}}\right)$, $67.0\left(\mathrm{CH}^{\mathrm{B}}\right), 66.6\left(\mathrm{CH}^{\mathrm{B}}\right), 66.4\left(\mathrm{CH}^{\mathrm{A}}\right), 55.3\left(\mathrm{CH}_{3}{ }^{\mathrm{A}}+\mathrm{CH}_{3}{ }^{\mathrm{B}}\right), 52.0$ $\left(\mathrm{CH}_{2}{ }^{\mathrm{B}}\right), 51.5\left(\mathrm{CH}_{2}{ }^{\mathrm{A}}\right), 33.4\left(\mathrm{CH}_{3}{ }^{\mathrm{B}}\right), 33.2\left(\mathrm{CH}_{2}{ }^{\mathrm{B}}\right), 33.1\left(\mathrm{CH}_{3}{ }^{\mathrm{A}}\right), 32.9$ $\left(\mathrm{CH}_{2}{ }^{\mathrm{A}}\right), 31.3\left(\mathrm{CH}_{2}{ }^{\mathrm{A}}+\mathrm{CH}_{2}{ }^{\mathrm{B}}\right), 30.2\left(\mathrm{CH}_{2}{ }^{\mathrm{B}}\right), 30.0\left(\mathrm{CH}_{2}{ }^{\mathrm{A}}\right), 28.7\left(\mathrm{CH}_{2}{ }^{\mathrm{A}}\right)$, $28.5\left(\mathrm{CH}_{2}{ }^{\mathrm{B}}\right)$. IR (neat): $1612(\mathrm{~m}), 1512$ (s), 1489 (m), 1450 (s), 1246 (s). HRMS (EI, $70 \mathrm{eV}$ ): calcd for $\mathrm{C}_{42} \mathrm{H}_{42} \mathrm{FeIN} \mathrm{INR}_{2} \mathrm{ORh}\left(\mathrm{M}^{+}\right)$ 876.0746, found 876.0768.

Rh-NHC Complex 46. According to General Procedure IV, reaction between imidazolinium iodide $32(208 \mathrm{mg}, 0.5 \mathrm{mmol})$, $\mathrm{KO}^{t} \mathrm{Bu}(56 \mathrm{mg}, 0.5 \mathrm{mmol}),[\mathrm{Rh}(\mathrm{cod}) \mathrm{Cl}]_{2}(118 \mathrm{mg}, 0.24 \mathrm{mmol})$, and KI (249 mg, $1.5 \mathrm{mmol})$, followed by flash column chromatography, afforded $46(238 \mathrm{mg}, 79 \%)$ as a $82: 18$ mixture of rotamers as an orange-yellow solid. Main isomer: ${ }^{1} \mathrm{H}$ NMR $(250 \mathrm{MHz}$, $\left.\mathrm{CDCl}_{3}\right): \delta(\mathrm{ppm}) 8.18(\mathrm{~d}, J=8.7 \mathrm{~Hz}, 2 \mathrm{H}), 7.68(\mathrm{~d}, J=8.7 \mathrm{~Hz}$, $2 \mathrm{H}), 5.65-5.50(\mathrm{~m}, 1 \mathrm{H}), 5.15-5.03(\mathrm{~m}, 2 \mathrm{H}), 4.34(\mathrm{~d}, J=3.9 \mathrm{~Hz}$, $1 \mathrm{H}), 3.74-3.65(\mathrm{~m}, 1 \mathrm{H}), 3.60-3.42(\mathrm{~m}, 2 \mathrm{H}), 3.25(\mathrm{~s}, 3 \mathrm{H}), 2.28-$ $2.11(\mathrm{~m}, 4 \mathrm{H}), 2.05-1.69(\mathrm{~m}, 5 \mathrm{H}), 1.31(\mathrm{~d}, J=7.0 \mathrm{~Hz}, 3 \mathrm{H}), 1.19$ $(\mathrm{d}, J=6.7 \mathrm{~Hz}, 3 \mathrm{H}), 0.89(\mathrm{~d}, J=6.9 \mathrm{~Hz}, 3 \mathrm{H}), 0.71(\mathrm{~d}, J=6.7 \mathrm{~Hz}$, $3 \mathrm{H}) .{ }^{13} \mathrm{C} \mathrm{NMR}\left(63 \mathrm{MHz}, \mathrm{CDCl}_{3}\right): \delta(\mathrm{ppm}) 213.7(\mathrm{~d}, J=44.5 \mathrm{~Hz}$, C), $147.8(\mathrm{C}), 147.3(\mathrm{C}), 128.1(2 \times \mathrm{CH}), 124.5(2 \times \mathrm{CH}), 97.7(\mathrm{~d}$, $J=6.4 \mathrm{~Hz}, \mathrm{CH}), 97.1(\mathrm{~d}, J=6.3 \mathrm{~Hz}, \mathrm{CH}), 72.1(\mathrm{~d}, J=18.5 \mathrm{~Hz}$, $\mathrm{CH}), 71.2(\mathrm{~d}, J=15.8 \mathrm{~Hz}, \mathrm{CH}), 71.0(\mathrm{CH}), 66.3(\mathrm{CH}), 51.5(\mathrm{CH})$, $35.9\left(\mathrm{CH}_{3}\right), 32.3\left(\mathrm{CH}_{2}\right), 32.2\left(\mathrm{CH}_{2}\right), 30.7(\mathrm{CH}), 29.4\left(\mathrm{CH}_{2}\right), 29.3$ 


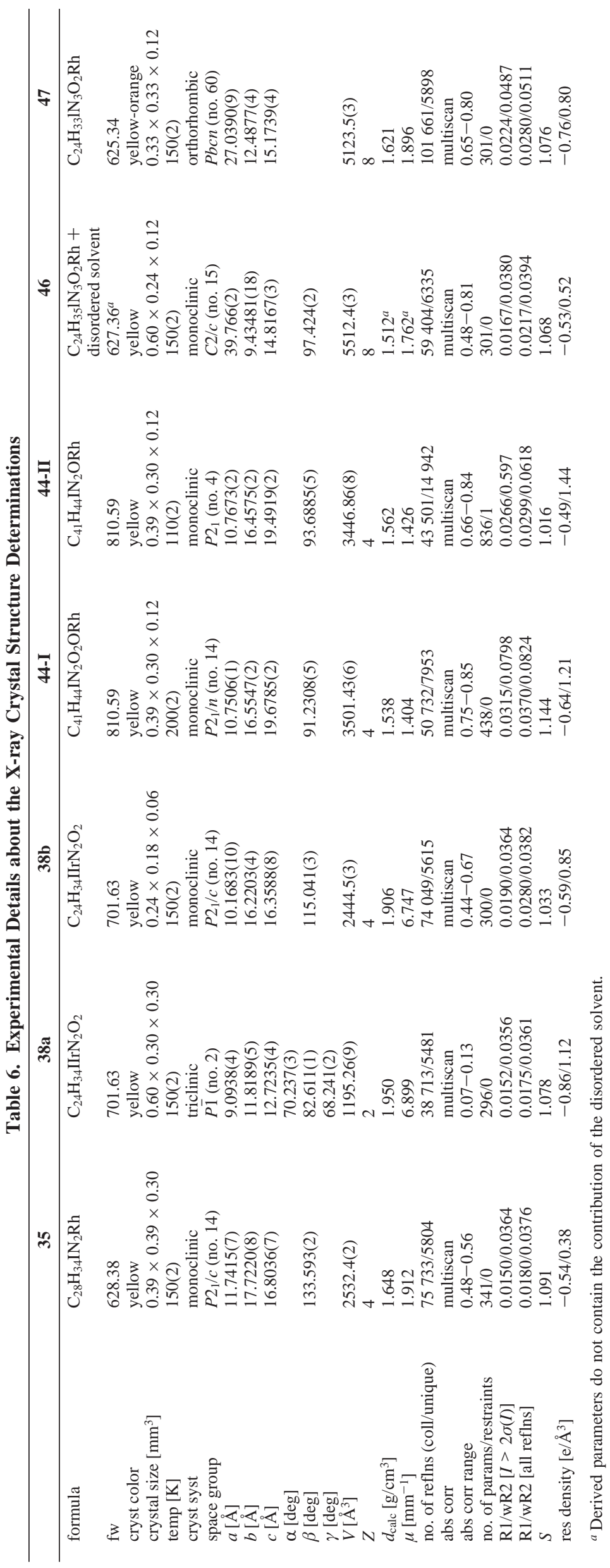


$\left(\mathrm{CH}_{2}\right), 23.1\left(\mathrm{CH}_{3}\right), 20.3\left(\mathrm{CH}_{3}\right), 18.3\left(\mathrm{CH}_{3}\right), 13.6\left(\mathrm{CH}_{3}\right)$. IR (neat): 1523 (s), 1446 (m), 1346 (s), 1188 (m). HRMS (EI, 70 eV): calcd for $\mathrm{C}_{24} \mathrm{H}_{35} \mathrm{IN}_{3} \mathrm{O}_{2} \mathrm{Rh}\left(\mathrm{M}^{+}\right)$627.0829, found 627.0803. Crystals suitable for $\mathrm{X}$-ray crystal structure determination were obtained by the slow diffusion of pentane into a saturated solution of $\mathbf{4 6}$ in DCM. Mp: $136-139^{\circ} \mathrm{C}$.

Rh-NHC Complex 47. According to General Procedure IV, reaction between imidazolium iodide $34(112 \mathrm{mg}, 0.27 \mathrm{mmol}), \mathrm{KO}^{t_{-}}$ $\mathrm{Bu}(31 \mathrm{mg}, 0.28 \mathrm{mmol}),[\mathrm{Rh}(\operatorname{cod}) \mathrm{Cl}]_{2}(67 \mathrm{mg}, 0.135 \mathrm{mmol})$, and $\mathrm{KI}$ (135 mg, $0.81 \mathrm{mmol})$, followed by flash column chromatography, afforded 47 (80 mg, 46\%) as an orange-yellow solid. ${ }^{1} \mathrm{H}$ NMR $\left(250 \mathrm{MHz}, \mathrm{CDCl}_{3}\right): \delta(\mathrm{ppm}) 8.25(\mathrm{~d}, J=7.5 \mathrm{~Hz}, 2 \mathrm{H}), 7.43(\mathrm{~d}, J$ $=7.4 \mathrm{~Hz}, 2 \mathrm{H}), 6.19-5.96(\mathrm{~m}, 1 \mathrm{H}), 5.23-5.04(\mathrm{~m}, 2 \mathrm{H}), 3.55(\mathrm{~s}$, $3 \mathrm{H}), 3.52-3.40(\mathrm{~m}, 2 \mathrm{H}), 3.29-3.08(\mathrm{~m}, 1 \mathrm{H}), 2.36-2.11(\mathrm{~m}, 4 \mathrm{H})$, $1.95-1.63(\mathrm{~m}, 4 \mathrm{H}), 1.62(\mathrm{~d}, J=7.9 \mathrm{~Hz}, 3 \mathrm{H}), 1.58(\mathrm{~d}, J=9.6 \mathrm{~Hz}$, $3 \mathrm{H}), 1.04-0.83(\mathrm{~m}, 6 \mathrm{H}) .{ }^{13} \mathrm{C}$ NMR $\left(63 \mathrm{MHz}, \mathrm{CDCl}_{3}\right): \delta(\mathrm{ppm})$ 180.0 (d, $J=48.8 \mathrm{~Hz}, \mathrm{C}$ ), 148.3 (C), 137.1 (C), 137.0 (C), 132.6 $(2 \times \mathrm{CH}), 129.3(\mathrm{C}), 123.7(2 \times \mathrm{CH}), 96.2(\mathrm{~d}, J=6.8 \mathrm{~Hz}, \mathrm{CH}), 95.7$ $(\mathrm{d}, J=6.8 \mathrm{~Hz}, \mathrm{CH}), 71.5(\mathrm{~d}, J=14.4 \mathrm{~Hz}, \mathrm{CH}), 70.8(\mathrm{~d}, J=14.0$ $\mathrm{Hz}, \mathrm{CH}), 54.0(\mathrm{CH}), 35.9\left(\mathrm{CH}_{3}\right), 32.4\left(\mathrm{CH}_{2}\right), 32.1\left(\mathrm{CH}_{2}\right), 29.7$ $\left(\mathrm{CH}_{2}\right), 29.4\left(\mathrm{CH}_{2}\right), 25.4(\mathrm{CH}), 23.1\left(\mathrm{CH}_{3}\right), 22.8\left(\mathrm{CH}_{3}\right), 22.6\left(\mathrm{CH}_{3}\right)$, $21.8\left(\mathrm{CH}_{3}\right)$. IR (neat): 1522 (s), 1342 (s). HRMS (EI, $\left.70 \mathrm{eV}\right)$ : calcd for $\mathrm{C}_{24} \mathrm{H}_{33} \mathrm{IN}_{3} \mathrm{O}_{2} \mathrm{Rh}\left(\mathrm{M}^{+}\right)$625.0672, found 625.0653. Crystals suitable for X-ray crystal structure determination were obtained by the slow diffusion of pentane into a saturated solution of $\mathbf{4 7}$ in DCM. Mp: $223-225^{\circ} \mathrm{C}$ (dec).

Crystal Structure Determinations. X-ray intensities were measured on a Nonius KappaCCD diffractometer with rotating anode (graphite monochromator, $\lambda=0.71073 \AA$ ) up to a resolution of $(\sin \theta / \lambda)_{\max }=0.65 \AA^{-1}$. The structures were solved with automated Patterson methods ${ }^{33}$ and refined with SHELXL-97 $7^{34}$ against $F^{2}$ of all reflections. Non hydrogen atoms were refined with anisotropic displacement parameters. Hydrogen atoms were introduced in calculated positions (44-II) or located in the difference Fourier map (all other structures). Geometry calculations and checking for higher symmetry was performed with the PLATON program. ${ }^{35}$ Further experimental details are given in Table 6. In 35 the $\mathrm{H}$ atoms of the cod ligand were refined freely with isotropic displacement parameters; all other $\mathrm{H}$ atoms were refined with a

(31) Schenck, T. G.; Downes, J. M.; Milne, C. R. C.; Mackenzie, P. B.; Boucher, H.; Whelan, J.; Bosnich, B. Inorg. Chem. 1985, 24, 2334-2337.

(32) Wehman-Ooyevaar, I. C. M.; Drenth, W.; Grove, D.; van Koten, G. Inorg. Chem. 1993, 32, 3347-3356.

(33) Beurskens, P. T.; Admiraal, G.; Beurskens, G.; Bosman, W. P.; Garcia-Granda, S.; Gould, R. O.; Smits, J. M. M.; Smykalla, C. The DIRDIF99 program system, Technical Report of the Crystallography Laboratory; University of Nijmegen: The Netherlands, 1999.

(34) Sheldrick, G. M. SHELXL-97, Program for crystal structure refinement; University of Göttingen: Germany, 1997.

(35) Spek, A. L. J. Appl. Crystallogr. 2003, 36, 7-13. riding model. In $\mathbf{3 8 a}$ and $\mathbf{3 8 b}$ the $\mathrm{H}$ atoms at $\mathrm{C} 3$ and at the cod double bonds were refined freely with isotropic displacement parameters; all other $\mathrm{H}$ atoms were refined with a riding model. Data sets for 44-I and 44-II were measured on the same crystal at different temperatures. While over a wide temperature range (110$250 \mathrm{~K}$ ) both phases are present, at $200 \mathrm{~K}$ the $P 2_{1} / n$ phase $(44-\mathrm{I})$ has higher intensity and at $110 \mathrm{~K}$ the $P 2_{1}$ phase (44-II). Only these major components were integrated using the HKL2000 software. ${ }^{36}$ 44-II was refined in a nonstandard setting of space group $P 2_{1}$ with an origin shift of $(0.25,0,0.25)$ to obtain consistent coordinates with respect to the high-temperature phase $P 2_{1} / n$ of 44-I (group/ subgroup relationship of the phase transition). In 44-I the $\mathrm{H}$ atoms at $\mathrm{C} 3$ and at the cod double bonds were refined freely with isotropic displacement parameters; all other $\mathrm{H}$ atoms were refined with a riding model. In 44-II all $\mathrm{H}$ atoms were refined with a riding model. 44-II was refined as an inversion twin resulting in a Flack parameter $x=0.183(9){ }^{37}$ The crystal structure of $\mathbf{4 6}$ contains large voids (596.4 $\AA^{3}$ /unit cell) filled with disordered solvent molecules. Their contribution to the structure factors was secured by back-Fourier transformation using the SQUEEZE routine of the program PLATON, ${ }^{35}$ accounting for 137 electrons/unit cell. The $\mathrm{H}$ atoms at the cod double bonds were refined freely with isotropic displacement parameters; all other $\mathrm{H}$ atoms were refined with a riding model. In 47 the $\mathrm{H}$ atoms at the cod double bonds were refined freely with isotropic displacement parameters; all other $\mathrm{H}$ atoms were refined with a riding model. For crystallographic data see also CCDC 612936 (35), 612937 (38a), 612938 (38b), 612939 (44-I), 612940 (44-II), 612941 (46), and 612942 (47).

Acknowledgment. Dr. Marek Smoluch (Vrije Universiteit Amsterdam) is gratefully acknowledged for conducting EI-(HR)MS measurements. Andreas Brockmeyer (Max Planck Institute for Molecular Physiology, Dortmund) is kindly thanked for conducting ESI-(HR)MS measurements. Elemental analyses have been measured at the Westfälischen Wilhelms-Universität Münster. This work was partially supported (M.L., A.L.S.) by the Council for Chemical Sciences of Netherlands Organization for Scientific Research (CW-NWO).

Supporting Information Available: Full crystallographic data for compounds 35, 38a, 38b, 44-I, 44-II, 46, and 47 are available as CIF files. This material is available free of charge via the Internet at http://pubs.acs.org.

\section{OM070168U}

(36) Otwinowski, Z.; Minor, W. Methods in Enzymology; Carter, C. W., Jr., Sweet, R. M., Eds.; Academic Press: New York, 1997; Vol. 276, pp 307-326.

(37) Flack, H. D. Acta Crystallogr. 1983, A39, 876-881. 